\title{
Quantifying the role of fire in the Earth system - Part 1: Improved global fire modeling in the Community Earth System Model (CESM1)
}

\author{
F. $\mathbf{L i}^{1}$, S. Levis ${ }^{2}$, and D. S. Ward ${ }^{3}$ \\ ${ }^{1}$ International Center for Climate and Environmental Sciences, Institute of Atmospheric Physics, Chinese Academy of \\ Sciences, Beijing, China \\ ${ }^{2}$ Terrestrial Sciences Section, Climate and Global Dynamics Division, National Center for Atmospheric Research, Boulder, \\ Colorado, USA \\ ${ }^{3}$ Department of Earth and Atmospheric Science, Cornell University, Ithaca, New York, USA
}

Correspondence to: F. Li (lifang@mail.iap.ac.cn)

Received: 5 November 2012 - Published in Biogeosciences Discuss.: 23 November 2012

Revised: 10 March 2013 - Accepted: 14 March 2013 - Published: 8 April 2013

\begin{abstract}
Modeling fire as an integral part of an Earth system model (ESM) is vital for quantifying and understanding fire-climate-vegetation interactions on a global scale and from an Earth system perspective. In this study, we introduce to the Community Earth System Model (CESM) the new global fire parameterization proposed by Li et al. (2012a, b), now with a more realistic representation of the anthropogenic impacts on fires, with a parameterization of peat fires, and with other minor modifications. The improved representation of the anthropogenic dimension includes the first attempt to parameterize agricultural fires, the economic influence on fire occurrence, and the socioeconomic influence on fire spread in a global fire model - also an alternative scheme for deforestation fires.

The global fire parameterization has been tested in CESM1's land component model CLM4 in a 1850-2004 transient simulation, and evaluated against the satellite-based Global Fire Emission Database version 3 (GFED3) for 1997-2004. The simulated 1997-2004 average global totals for the burned area and fire carbon emissions in the new fire

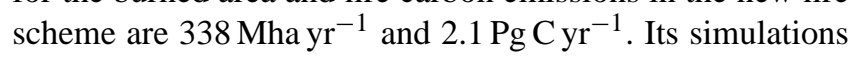
on multi-year average burned area, fire seasonality, fire interannual variability, and fire carbon emissions are reasonable, and show better agreement with GFED3 than the current fire scheme in CESM1 and modified CTEM-FIRE. Moreover, the new fire scheme also estimates the contributions of global fire carbon emissions from different sources. Dur-
\end{abstract}

ing 1997-2004, the contributions are $8 \%$ from agricultural biomass burning, $24 \%$ from tropical deforestation and degradation fires, $6 \%$ from global peat fires $(3.8 \%$ from tropical peat fires), and $62 \%$ from other fires, which are close to previous assessments based on satellite data, government statistics, or other information sources. In addition, we investigate the importance of direct anthropogenic influence (anthropogenic ignitions and fire suppression) on global fire regimes during 1850-2004, using CESM1 with the new fire scheme. Results show that the direct anthropogenic impact is the main driver for the long-term trend of global burned area, but hardly contributes to the long-term trend of the global total of fire carbon emissions.

\section{Introduction}

Fire is an important Earth system process on a global scale (Bowman et al., 2009). It depends on vegetation characteristics, climate, and human activities, and generates feedbacks by affecting biogeochemical cycles, vegetation composition and structure, land-atmosphere water and heat exchanges, atmospheric chemistry and composition, and human health and property (Bond et al., 2004; IPCC, 2007; Cochrane and Ryan, 2009; Bond-Lamberty et al., 2009; van der Werf et al., 2010; Bowman et al., 2011). To quantify the role of fire in the Earth system on a global scale from an Earth 
system perspective and project global change with variable fire regimes, it is vital to model fire as an integral part of an Earth system model (ESM). An ESM with a representation of the anthropogenic impact on fires may also help identify appropriate and sustainable strategies for fire management.

Existing global fire parameterizations suitable for ESMs aim to best match the observed fire regimes for the contemporary time period, given that only the contemporary global fire product is available with a sufficient quality to be used as evaluation data (Kloster et al., 2010; Prentice et al., 2011). These global fire parameterizations are generally large scale $\left(10^{3}-10^{5} \mathrm{~km}^{2}\right)$, and simplify the real world at various levels to improve the efficiency of computations. MC-FIRE is the first fire parameterization used in a dynamic global vegetation model (DGVM, a type of ecosystem model in ESM) (Lenihan et al., 1998). Then, Thonicke et al. (2001) proposed the most widely used fire scheme, Glob-FIRM. Arora and Boer (2005) introduced CTEM-FIRE in CTEM-DGVM, which was a process-based fire model of intermediate complexity as Glob-FIRM but considering the effect of wind speed on fire spread and certain anthropogenic effects on fire regimes. N. M. Mahowald (personal communication, 2012) modified Glob-FIRM by translating the original annual into a sub-daily time step to simulate fire seasonality in the Community Land Model version 4 (CLM4), the land component model of the Community Earth System Model version 1 (CESM1) (Oleson et al., 2010). Kloster et al. (2010) modified CTEM-FIRE by introducing anthropogenic ignition and fire suppression schemes from Pechony and Shindell (2009) and adding a parameterization of deforestation fires. Kloster et al. (2010) applied the modified CTEM-FIRE in an unreleased version of CLM4 and pointed out that their modification can substantially improve the global fire simulations. Later, in the framework of LPJ-DGVM, Thonicke et al. (2010) proposed SPITFIRE, a complex process-based fire model similar to MC-FIRE but based on the full Rothermel model for the calculation of surface fire intensity and fire-induced crown and cambial damage. A modified version of SPITFIRE was used in LPX-DGVM by Prentice et al. (2011).

Most recently, Li et al. (2012a, b) developed a processbased fire model of intermediate complexity that contained three components: fire occurrence, fire spread, and fire impact (Fig. 1). Burned area in a grid cell was estimated by the product of fire counts and average burned area of a fire. It has some advantages compared with other processbased fire models of intermediate complexity (Glob-FIRM, CTEM-FIRE, and their modified versions). First, unlike the fire probability $(\leq 1)$ used in other fire models, the fire counts have no mathematical upper limit, so there is no need to assume representative area or time step to avoid the underestimation of burned areas in regions with a high fire frequency. Second, MODIS provides observations for the fire counts, so the parameters in the fire occurrence component can be estimated objectively. Third, the post-fire region of a fire is assumed to be elliptical in shape in the fire spread com-

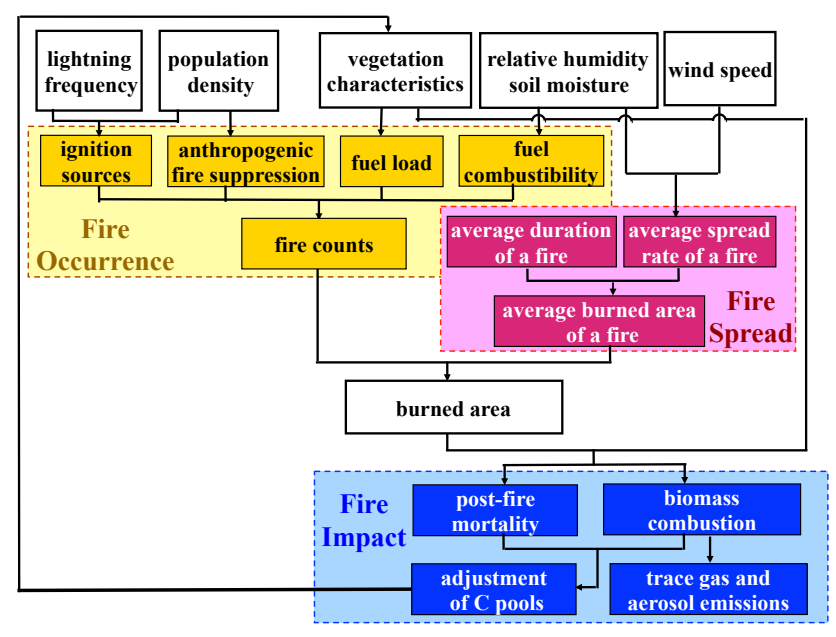

Fig. 1. Fire parameterization of Li et al. (2012a, b). It contains three components: fire occurrence, fire spread, and fire impact.

ponent. The mathematical properties of ellipses and some mathematical derivations are used to improve the equation and assumptions of an existing fire spread parameterization. In addition, trace gas and aerosol emissions due to biomass burning are estimated in the fire impact component, which offers an interface with atmospheric chemistry and aerosol models in ESMs. Its global performance was evaluated using a modified CLM-DGVM (Levis et al., 2004; Zeng et al., 2008; Zeng, 2010), and the results showed that the simulated global total amount and spatial distribution of burned area and fire emissions were broadly consistent with the satellitebased GFED3 fire product.

Global fire parameterizations need further improvements, especially with respect to the representation of the human dimension of fire regimes. First, fires are used worldwide to clear agricultural residue, fertilize the soil, and eliminate pests (Chidumayo, 1987; Le Page et al., 2010a). Agricultural fires account for 8-11\% of the 2001-2003 global annual fire counts (Korontzi et al., 2006) and significantly change fire seasonality in many regions (Le Page et al., 2010a; Magi et al., 2012). These fires emit large amounts of hydrocarbons, nitrogen oxides, carbon monoxide, which are the precursors of tropospheric ozone and influence the chemistry of the OH radical (Logan et al., 1981, Logan, 1985), and smoke aerosols with significant consequences on human health (World Health Organization (WHO), 2000). Earlier global fire models assumed that there were no fires in cropland (Arora and Boer, 2005; Kloster et al., 2010; Thonicke et al., 2010; Prentice et al., 2011), or neglected any differences from non-agricultural fires, e.g., the current fire model in CESM1 (N. M. Mahowald, personal communication, 2012; Oleson et al., 2010). Second, deforestation fires and peat fires are important sources of fire carbon emissions (van der Werf et al., 2010). Of all the previous global fire models, only the modified CTEM-FIRE 
(Kloster et al., 2010) included deforestation fires based on land use change data. In Kloster et al. (2010), the fires in a grid cell were simulated as the sum of deforestation fires and fires due to natural and anthropogenic (intentional and accidental) ignitions. So far, no global fire model includes peat fires. The ESMs that do not include peat fires cannot simulate some large fires and associated extreme air pollution events, such as the famous 1997 Southeast Asian haze that lasted several months and was caused by tropical peat fires and deforestation fires in Indonesia (http://en.wikipedia.org/wiki/ 1997_Southeast_Asian_haze), or the 2010 Russian Haze due to boreal peat fires and forest fires (http://en.wikipedia.org/ wiki/2010_Russian_wildfires). Third, only the effect of population density on fire occurrence has been considered in earlier studies (Pechony and Shindell, 2009; Kloster et al., 2010; Thonicke et al., 2010; Li et al., 2012a). Other anthropogenic impacts on fires, for example, the fire management and firefighting capability related to countries' socioeconomic situations (Chuvieco et al., 2008; Aldersley et al., 2011), have yet to be considered.

The aim of the present study is to introduce an expanded version of the $\mathrm{Li}$ et al. (2012a, b) fire parameterization to the CESM. The expanded version includes a more realistic representation of anthropogenic impacts on fires, the parameterization of peat fires, and other minor modifications. The more realistic representation of anthropogenic impacts includes the first attempt to parameterize agricultural fires, the economic influence on fire occurrence, and the socioeconomic influence on fire spread in a global fire model; also an alternative scheme of deforestation fires. Its global performance in CESM1 is evaluated against the satellite-based Global Fire Emission Database version 3 (GFED3) (Giglio et al., 2010; van der Werf et al., 2010), and compared with the current fire parameterization implemented in CESM1 (N. M. Mahowald, personal communication, 2012; Oleson et al., 2010) and the modified CTEM-FIRE (Kloster et al., 2010). Methodologically, compared with the two fire schemes, the new fire scheme of CESM has not only the advantages of the Li et al. (2012a, b) fire scheme (see third paragraph in Sect. 1) but also the Li et al. (2012a, b) future improvements listed above.

In this paper, Sect. 2 presents the data used to calibrate, drive and evaluate the model. Section 3 describes the new fire parameterization scheme. Section 4 introduces its application in CESM1 and simulations. Section 5 evaluates the global fire simulations. Based on the new fire parameterization, Sect. 6 investigates the importance of direct anthropogenic influence on the long-term trend of global fire regimes since the middle of the 19th century. Conclusions and future development appear in Sect. 7.

\section{Data}

Table 1 lists data used in the present study. The 1997-2009 monthly burned area and fire carbon emissions data at a $0.5^{\circ}$ spatial resolution are provided by GFED3 (Giglio et al., 2010; van der Werf et al., 2010). The GFED3 burned area is a mixture of observations and satellite-based estimates, which are generated from $500 \mathrm{~m}$ MODIS burned area maps (MCD64A1), active fire detections from multiple satellites, local regression, and regional regression trees (Giglio et al., 2010; L. Giglio, personal communication, 2012). The GFED3 fire emissions data are the output of a revised CASA biogeochemical model driven by the GFED3 burned area, MODIS vegetation and land data, active fire detections from multiple satellites, weather observations, MODIS photosynthetically active radiation, and AVHRR NDVI data (van der Werf et al., 2010). The GFED3 fire product represents the most comprehensive attempt to date to derive the burned area and fire emissions from remote sensing data, and it is suitable for calibrating functions and parameters as well as for evaluating present-day simulations of global fire models (van der Werf et al., 2010; Prentice et al., 2011). The MODIS 0.5 global monthly fire count product for 2001-2010 can be obtained from ftp://fuoco.geog.umd.edu (Giglio et al., 2006).

The 1948-2004 $3 \mathrm{~h}$ surface air temperature, wind speed, specific humidity, and air pressure, and $6 \mathrm{~h}$ downward solar radiation data and precipitation at a T62 $\left(\sim 1.875^{\circ}\right)$ spatial resolution are the atmospheric data that drive the CLM4 (Qian et al., 2006). The 1948-2004 6h reanalysis relative humidity data at a $2.5^{\circ}$ spatial resolution are derived from the National Centers for Environmental Prediction/National Center for Atmospheric Research (NCEP/NCAR) (Kalnay et al., 1996), which are biascorrected using the 10 monthly Climate Research Unit (CRU) climatological data (New et al., 1999, 2000) according to the method of Qian et al. (2006). NASA LIS/OTD grid product v2.2 (http://ghrc.msfc.nasa.gov) provides the $2.5^{\circ}$ daily lightning time series from May 1995 to December $2004(4260 \times 144 \times 73)$ and $2 \mathrm{~h}$ climatological lightning data $(365 \times 12 \times 144 \times 73)$.

The population density data for $1990,1995,2000$, and 2005 at a $0.5^{\circ}$ spatial resolution are provided by the Gridded Population of the World version 3 (GPWv3) (CIESIN, 2005). The 5 min decadal population density data for $1850-1980$ are from the Database of the Global Environment version 3.1(HYDEv3.1) (Klein Goldewijk et al., 2010). Gross domestic production (GDP) per capita in 2000 and at a $0.5^{\circ}$ spatial resolution is from Van Vuuren et al. (2006), which is the base-year GDP data for IPCC-SRES and derived from country-level World Bank's World Development Indicators (WDIs) measured in constant 1995 US\$ (World Bank, 2004) and the UN Statistics Database (UNSTAT, 2005). The peatland area fraction at a $0.5^{\circ}$ spatial resolution is derived from three vector datasets: peatland data in Indonesia and Malaysian Borneo (Olson et al., 2001); peatland data in 
Table 1. Datasets. Note that default datasets in CESM1 that are just used to drive the model are not included here.

\begin{tabular}{|c|c|c|}
\hline Variables & Sources & Resolutions \\
\hline $\begin{array}{l}\text { Burned area } \\
\text { Fire emissions }\end{array}$ & $\begin{array}{l}\text { GFED3 (Giglio et al., 2010; } \\
\text { van der Werf et al., 2010) }\end{array}$ & $0.5^{\circ}$, monthly \\
\hline Fire counts & MODIS (Giglio et al., 2006) & $0.5^{\circ}$, monthly \\
\hline $\begin{array}{l}\text { Surface air temperature } \\
\text { Wind speed } \\
\text { Specific humidity } \\
\text { Air pressure } \\
\text { Precipitation } \\
\text { Incoming solar radiation }\end{array}$ & Qian et al. (2006) & T62 ( 1.875 $), 3$-hourly \\
\hline Relative humidity & $\begin{array}{l}\text { NCEP/NCAR (Kalnay et al., 1996); } \\
\text { CRU (New et al., 1999, 2000) }\end{array}$ & $\begin{array}{l}2.5^{\circ}, 6 \text {-hourly } \\
10 \text { min, monthly* }\end{array}$ \\
\hline Lightning frequency & $\begin{array}{l}\text { NASA LIS/OTD v2.2 } \\
\text { (http://ghrc.msfc.nasa.gov) }\end{array}$ & $\begin{array}{l}2.5^{\circ}, 2 \text {-hourly* } \\
2.5^{\circ}, \text { daily }\end{array}$ \\
\hline Population density & $\begin{array}{l}\text { GPWv3 (CIESIN, 2005); } \\
\text { HYDE v3.1 (Klein Goldewijk et al., 2010) }\end{array}$ & $\begin{array}{l}0.5^{\circ}, 5 \mathrm{yr} \\
5 \mathrm{~min}, 10 \mathrm{yr}\end{array}$ \\
\hline Gross domestic product (GDP) & van Vuuren et al. (2006) & $0.5^{\circ}$, in 2000 \\
\hline Peat area fraction & $\begin{array}{l}\text { Olson et al. (2001); } \\
\text { Tarnocai et al. (2011); } \\
\text { GLWD (Lehner and Döll, 2004) }\end{array}$ & vector, for present day \\
\hline $\begin{array}{l}\text { Peak month of agricultural } \\
\text { waste burning }\end{array}$ & van der Werf et al. (2010) & $0.5^{\circ}$, for present day \\
\hline $\begin{array}{l}\text { Land use and land } \\
\text { cover change (LULCC) }\end{array}$ & CLM4 land surface data & $0.47^{\circ} \times 0.63^{\circ}$, annual \\
\hline Present-day land cover & & $0.47^{\circ} \times 0.63^{\circ}$, for present day \\
\hline
\end{tabular}

Canada (Tarnocai et al., 2011); and bog, fen and mire data in boreal regions (north of $45^{\circ} \mathrm{N}$ ) outside Canada provided by the Global Lakes and Wetlands Database (GLWD) (Lehner and Döll, 2004). The climatological peak month data for agricultural waste burning at a $0.5^{\circ}$ resolution (van der Werf et al., 2010) are used to estimate the timing of agricultural fires. The annual $0.47^{\circ} \times 0.63^{\circ}$ land use and land cover change (LULCC) data for 1850-2005 and the present-day land cover data are from the CLM4 land surface data in CESM1 (Lawrence and Chase, 2007, 2010; Oleson et al., 2010). The LULCC data are based on version 1 of the LandUse History A product (LUHa.v1) (Hurtt et al., 2006), while the present-day data are based on the MODIS land surface data product (Justice et al., 2002; Hansen et al., 2003) and the cropping dataset of Ramankutty et al. (2008). The CLM represents vegetation as plant functional types (PFTs, Table 2) instead of species to generalize plant function on a global scale (Bonan et al., 2002). Thus, the land type data from various sources are translated into the PFT levels in the CLM4 land surface data (Oleson et al., 2010).

\section{Fire parameterization}

The new fire parameterization for CESM contains four components: agricultural fires in cropland (Region A), deforestation fires in the tropical closed forests (Region B), non-peat fires outside Regions A and B (Region C), and peat fires in all three regions (Fig. 2). In this fire parameterization, burned area is mainly affected by climate and weather conditions, vegetation composition and structure, and human activities. After burned area is calculated, we estimate the fire impact, including biomass and peat burning, and vegetation mortality in the post-fire region; adjustment of the carbon and nitrogen $(\mathrm{C} / \mathrm{N})$ pools; and trace gas and aerosol emissions due to fuel burning.

This fire parameterization is a further development of the work presented in detail by Li et al. (2012a, b). The Li et al. (2012a, b) parameterization (Fig. 1) is used here in region $\mathrm{C}$ with modifications, mainly from adding parameterizations about the economic influence in the fire occurrence component and the socioeconomic impact in the fire spread component. The current paper only describes the further 


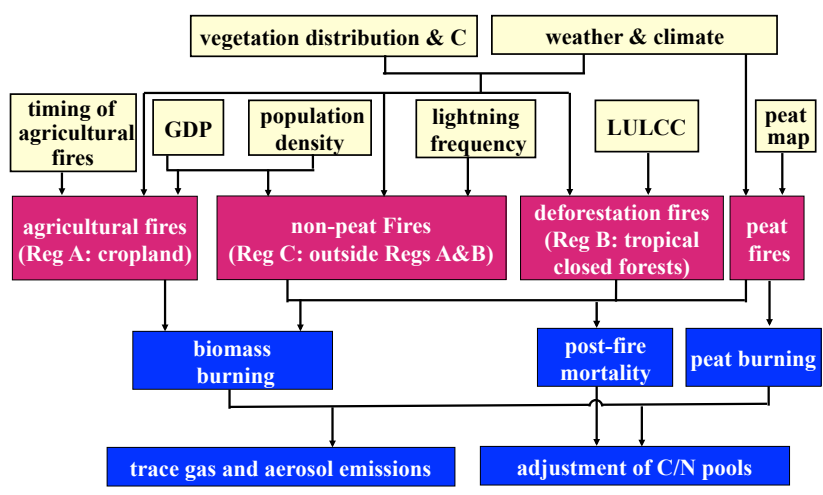

Fig. 2. Structure of new fire parameterization. Fire scheme described in $\mathrm{Li}$ et al. (2012a, b) is used in Region $\mathrm{C}$ with modifications by mainly adding the economic influence in the fire occurrence component and the socioeconomic influence in the fire spread component.

Table 2. Plant functional types (PFTs) used in the present study.

\begin{tabular}{ll}
\hline PFT & Abbreviation \\
\hline Trees & \\
Broadleaf Evergreen Tropical & BET Tropical \\
Broadleaf Deciduous Tropical & BDT Tropical \\
Broadleaf Evergreen Temperate & BET Temperate \\
Needleleaf Evergreen Temperate & NET Temperate \\
Broadleaf Deciduous Temperate & BDT Temperate \\
Needleleaf Evergreen Boreal & NET Boreal \\
Broadleaf Deciduous Boreal & BDT Boreal \\
Shrubs & \\
Broadleaf Deciduous Temperate & BDS Temperate \\
Broadleaf Deciduous Boreal & BDS Boreal \\
\hline Grasses & \\
C4 & - \\
C3 Non-arctic & - \\
C3 Arctic & - \\
\hline Crop & \\
Crop1 & - \\
Crop 2 & - \\
\hline
\end{tabular}

development of the Li et al. (2012a, b) scheme, i.e., the parameterization schemes of agricultural fires, deforestation fires, peat fires, economic impact on fire occurrence, socioeconomic impact on fire spread, and some minor modifications. Table A1 lists all variables and parameters used in the present study and their meanings and units.

\subsection{Agricultural fires}

Korontzi et al. (2006) used the MODIS active fire product to describe global patterns of agricultural fires and indicated that the fuel load could affect the interannual variability of agricultural fires. Moreover, as an anthropogenic activity, agricultural fires are greatly affected by socioeconomic conditions (Chuvieco et al., 2008; Bowman et al., 2011), and generally occur after harvesting or before planting, broadly different from the fire seasonality of non-agricultural fires (Le Page et al., 2010a; Magi et al., 2012). Thus, the burned area of cropland $\left(\mathrm{km}^{2}(\text { time step })^{-1}\right)$ is taken as

$A_{\mathrm{b}}=a_{1} f_{b} f_{\mathrm{se}} f_{t} f_{\text {crop }} A_{\mathrm{g}}$,

where constant $a_{1}$ ((time step $\left.)^{-1}\right)$ is estimated using an inverse method (see Sect. 4 ); $f_{b}$ is the fuel availability factor; $f_{\text {se }}$ represents the socioeconomic effect on fires; $f_{t}$ determines the seasonality of agricultural fires; $f_{\text {crop }}$ is the fractional coverage of cropland; and $A_{\mathrm{g}}$ is the area of the grid cell $\left(\mathrm{km}^{2}\right)$.

We assume that the fuel-load requirement of fires is universal, so $f_{b}$ is set the same as that used for non-cropland regions in $\mathrm{Li}$ et al. (2012a). The socioeconomic factor $f_{\mathrm{se}}$ is given as follows:

$f_{\mathrm{se}}=f_{\mathrm{d}} f_{\mathrm{e}}$.

Here

$f_{\mathrm{d}}=0.04+0.96 \times \exp \left[-\pi\left(\frac{D_{\mathrm{p}}}{350}\right)^{0.5}\right]$

and

$f_{\mathrm{e}}=0.01+0.99 \times \exp \left(-\pi \frac{\mathrm{GDP}}{10}\right)$

are the effects of population density $D_{\mathrm{p}}$ (person $\mathrm{km}^{-2}$ )

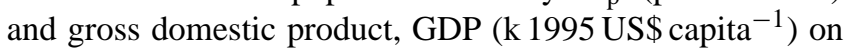
burned area, respectively, which are identified by maximizing the explained variability of the GFED3 burned area fraction with both socioeconomic indices in grid cells where the area fraction of cropland is $>50 \%$ (Fig. 3). Equations (3) and (4) reflect that less populated and less developed regions are more likely to use fires as a cheap and effective means of removing agricultural waste. $f_{t}$ is simply set to 1 for rainless time steps for 1 month after harvesting or before planting, or to 0 otherwise, which is supported by previous analyses of agricultural fire seasonality (Korontzi et al., 2006; Le Page et al., 2010a; Magi et al., 2012). The specific month for agriculture fires (month after harvesting or before planting) can be set for various crop types for ESMs that simulate the harvesting and planting date, or set as the climatological peak month for agricultural fires derived from van der Werf et al. (2010) as we do here.

In the post-fire region, carbon transfers from agricultural waste (litter) to the atmosphere. The combustion completeness factor is set to 0.8 , which is the same as that used for grass litter in Li et al. (2012a). Emission factors of trace gases and aerosols are shown in Table 3, which are based on Andreae and Merlet (2001) and M. O. Andreae (personal communication, 2011). 
Table 3. Emission factors of trace gases and aerosols ( $\mathrm{g}$ species $\left.(\mathrm{kg} \mathrm{dm})^{-1}\right) \cdot \mathrm{CO}_{2}$ : carbon dioxide, $\mathrm{CO}$ : carbon monoxide, $\mathrm{CH}_{4}$ : methane, $\mathrm{NMHC}$ : non-methane hydrocarbon, $\mathrm{H}_{2}$ : hydrogen gas, $\mathrm{NO}_{\mathrm{x}}$ : nitrogen oxides, $\mathrm{N}_{2} \mathrm{O}$ : nitrous oxide, $\mathrm{PM}_{2.5}$ : particles less than 2.5 micrometers in diameter, TPM: total particulate matter, TC: total carbon, OC: organic carbon, BC: black carbon.

\begin{tabular}{lcccccccccccc}
\hline & $\mathrm{CO}_{2}$ & $\mathrm{CO}$ & $\mathrm{CH}_{4}$ & $\mathrm{NMHC}$ & $\mathrm{H}_{2}$ & $\mathrm{NO}_{\mathrm{x}}$ & $\mathrm{N}_{2} \mathrm{O}$ & $\mathrm{PM}_{2.5}$ & $\mathrm{TPM}$ & $\mathrm{TC}$ & $\mathrm{OC}$ & $\mathrm{BC}$ \\
\hline $\begin{array}{l}\text { Agricultural } \\
\text { waste burning }\end{array}$ & 1473 & 95 & 8.0 & 9.9 & 2.7 & 2.4 & 0.1 & 8.0 & 12.4 & 4.6 & 4.2 & 0.4 \\
Peat fires $^{\mathrm{b}}$ & 1703 & 210 & 20.8 & 7.0 & 3.5 & 2.3 & 0.2 & 9.1 & 11.8 & 6.0 & 4.3 & 0.6 \\
\hline
\end{tabular}

${ }^{a}$ Based on Andreae and Merlet (2001) and M. O. Andreae (personal communication, 2011).

$\mathrm{b}$ Based on van der Werf et al. (2010)
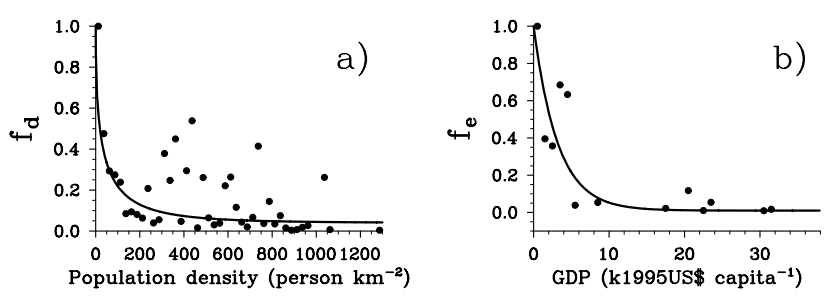

Fig. 3. Effects of (a) demographic situation $f_{\mathrm{d}}$, and (b) economic situation $f_{\mathrm{e}}$ on burned area fraction (lines). Population density (per-

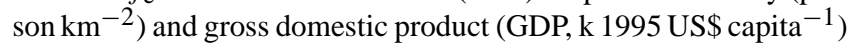
are used as socioeconomic indicators. In regions where area fraction of crop PFTs is larger than 50\%, we partition 1997-2004 average $0.5^{\circ}$ GFED3 burned area fraction divided by $f_{\mathrm{e}}$ (i.e., $\left.\left(\frac{A_{\mathrm{b}}}{A_{\mathrm{g}}}\right)_{\text {GFED } 3} / f_{\mathrm{e}}\right)$ over 25 person $\mathrm{km}^{-2}$ population density bins, and GFED3 burned area fraction divided by $f_{\mathrm{d}}$ (i.e., $\left.\left(\frac{A_{\mathrm{b}}}{A_{\mathrm{g}}}\right)_{\mathrm{GFED} 3} / f_{\mathrm{d}}\right)$

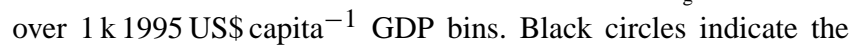
(normalized) average in bins with sample size $>5$. Goodness of fit is $R^{2}=0.46(n=42)$ in (a) and $R^{2}=0.70(n=13)$ in (b).

\subsection{Deforestation fires}

Of the existing global fire models, only modified CTEMFIRE (Kloster et al., 2010) simulated deforestation fires, in which fires in a grid cell were set as the sum of deforestation fires and fires due to natural and (intentional and accidental) human ignitions. The deforestation fires were assumed to occur whenever the land type was converted (e.g., from tree, grass or shrub PFTs to bare soil, from crop PFTs to grass or tree PFTs) and the soil was dry. This parameterization may lead to double-counting and, therefore, an overestimation of fire carbon emissions and especially the burned area due to intentional human ignitions in land-type conversion regions, given that deforestation fires are a type of fires due to intentional human ignitions and many land-type conversions do not involve deforestation.

Here we provide an alternative scheme to parameterize deforestation fires in global fire models. It focuses on deforestation fires in tropical closed forests. Tropical closed forests are defined as grid cells with tropical tree coverage $>60 \%$ according to the FAO classification. Deforestation fires are defined as fires caused by deforestation (including escaped de- forestation fires, termed degradation fires) outside cropland of these grid cells. To avoid overestimating fires due to anthropogenic intentional ignitions, the Li et al. (2012a, b) parameterization about fires due to natural and anthropogenic (intentional and accidental) ignitions is not used in these grid cells. In this way, fires due to natural and anthropogenic accidental ignitions are neglected, which are rare in these regions due to high humidity environments (van der Werf, et al., 2009; Le Page et al., 2010b). Deforestation fires are controlled by the deforestation rate and the climate conditions (Mortan et al., 2008; van der Werf et al., 2009; Le Page et al., $2010 \mathrm{~b}$ ), so the burned area is estimated as

$A_{\mathrm{b}}=b f_{\mathrm{lu}} f_{\mathrm{cli}, \mathrm{d}} A_{\mathrm{g}}$,

where $b\left((\text { time step })^{-1}\right)$ is a global constant; $f_{\text {lu }}$ and $f_{\text {cli, d }}$ represent the effects of decreased coverage fraction of tree PFTs derived from land use data and climate conditions on the burned area, respectively, and vary between 0.0 and 1.0.

The constant $b$ and $f_{\text {lu }}$ are calibrated in the Amazon rainforest (tropical closed forests within $15.5^{\circ} \mathrm{S}-10.5^{\circ} \mathrm{N}$, $30.5^{\circ} \mathrm{W}-91^{\circ} \mathrm{W}$ ). There are two reasons for our region selection: (i) the Amazon rainforest is the dominant tropical deforestation region (Hansen et al., 2008); (ii) the peat accumulation and cropland coverage are low in this region (GACGC, 2000; Hurtt et al., 2006), so the effects of peat fires and agricultural fires on the estimations of $b$ and $f_{\text {lu }}$ are small.

The constant $b=0.035 \mathrm{~d}^{-1}$ is based on Eq. (5) and the following three datasets: atmospheric observations (Qian et al., 2006), CLM4's land use and land cover change data (Oleson et al., 2010), and the GFED3 burned area (Giglio et al., 2009). The multi-year (1997-2004) averages of these data are regridded to the T62 resolution of the Qian et al. (2006) data.

$f_{\text {lu }}$ is defined as

$f_{\mathrm{lu}}=\max (0.0005,0.19 D-0.0011)$.

Equation (6) can explain $83 \%$ of the spatial variability of the 1997-2004 average $0.5^{\circ}$ GFED3 annual burned area fraction in grid cells with annual decreased tree coverage $D\left(\mathrm{yr}^{-1}\right)$ in the Amazon rainforest, and reflects that the burned area in tropical closed forests generally increases with greater losses 


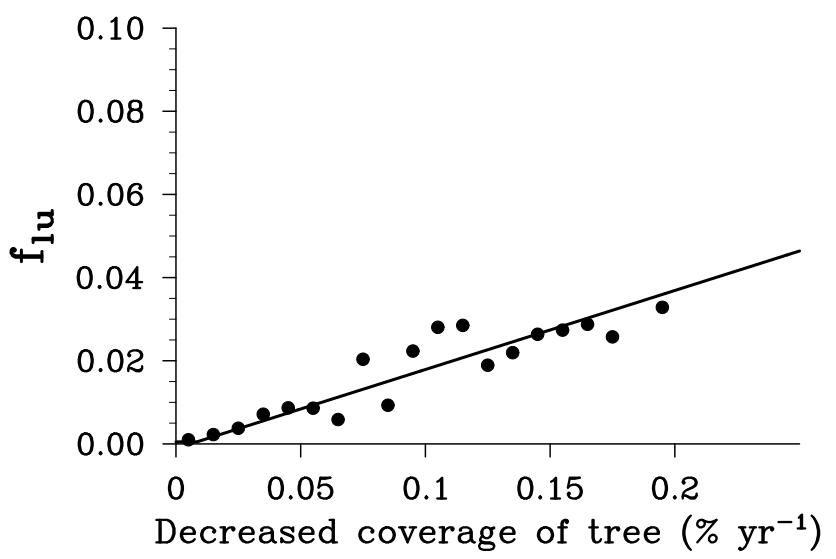

Fig. 4. Effects of decreases of tree coverage on annual burned area, $f_{\text {lu }}$ (line). $0.5^{\circ}$ GFED3 burned area fraction in Amazon rainforest (tropical closed forest in $15.25^{\circ} \mathrm{S}-10.25^{\circ} \mathrm{N}, 30.75-90.75^{\circ} \mathrm{W}$ ) is partitioned over $0.01 \% \mathrm{yr}^{-1}$ deforestation rate bins. Black circles indicate the average burned area fraction in bins with sample size $>5$. Goodness of fit is $0.83(n=19)$.

of tree coverage (Fig. 4). $D\left(\mathrm{yr}^{-1}\right)$ is based on CLM4's land use and land cover change data.

Fires in tropical closed forests only occur during the dry season, generally 2 months after the wet season has ended (Schroeder et al., 2005). On an intraseasonal time scale, 10day wet periods in the dry season can lead to a drop in the fire activity levels (Le Page et al., 2010b). To represent the impact of climate on fires, we use 60-day running mean of precipitation $\left(P_{60 \mathrm{~d}}, \mathrm{~mm} \mathrm{~d}^{-1}\right)$ to reflect the desiccation dynamics of these slashed trees during the dry season (Carvalho et al., 2001), and use the 10-day running mean of precipitation $\left(P_{10 \mathrm{~d}}, \mathrm{~mm} \mathrm{~d}^{-1}\right)$ to reflect the rapid variability of superficial moisture due to the daily weather (Uhl and Kauffman, 1990; Holdsworth and Uhl, 1997; Ray et al., 2005). We also assume that humans do not use fires to clear biomass in deforestation regions during the time step when precipitation $\left(P, \mathrm{~mm} \mathrm{~d}^{-1}\right)$ is greater than the level of drizzle $\left(0.25 \mathrm{~mm} \mathrm{~d}^{-1}\right)$. In total, we parameterize the effect of climate on deforestation fires as

$$
\begin{aligned}
f_{\mathrm{cli}, \mathrm{d}}= & \max \left[0, \min \left(1, \frac{b_{2}-P_{60 \mathrm{~d}}}{b_{2}}\right)\right]^{0.5} \max \left[0, \min \left(1, \frac{b_{3}-P_{10 \mathrm{~d}}}{b_{3}}\right)\right]^{0.5} \\
& \max \left[0, \min \left(1, \frac{0.25-P}{0.25}\right)\right],
\end{aligned}
$$

where $b_{2}\left(\mathrm{~mm} \mathrm{~d}^{-1}\right)$ and $b_{3}\left(\mathrm{~mm} \mathrm{~d}^{-1}\right)$ are the grid-cell dependent thresholds of $P_{60 \mathrm{~d}}$ and $P_{10 \mathrm{~d}}$, respectively. Le Page et al. (2010b) analyzed the relationship between large-scale deforestation fire counts and precipitation during 2003-2006 in southern Amazonia where tropical evergreen trees (BET Tropical) are dominant. Figure 2 in Le Page et al. (2010b) showed that fires generally occurred if both $P_{60 \mathrm{~d}}$ and $P_{10 \mathrm{~d}}$ were less than about $4.0 \mathrm{~mm} \mathrm{~d}^{-1}$, and fires occurred more frequently in a drier environment. Based on the $30 \mathrm{yr}$ (1985-2004) precipitation data in Qian et al. (2006), the climatological precipitation of dry months $\left(P<4.0 \mathrm{~mm} \mathrm{~d}^{-1}\right)$ in a year over tropical deciduous tree (BDT Tropical) dominated regions is $46 \%$ of that over BET Tropical dominated regions, so we set the PFT-dependent thresholds of $P_{60 \mathrm{~d}}$ and $P_{10 \mathrm{~d}}$ as $4.0 \mathrm{~mm} \mathrm{~d}^{-1}$ for BET Tropical and $1.8 \mathrm{~mm} \mathrm{~d}^{-1}\left(=4.0 \mathrm{~mm} \mathrm{~d}^{-1} \times 46 \%\right)$ for BDT Tropical, and $b_{2}$ and $b_{3}$ are the average of thresholds of BET Tropical and BDT Tropical weighted by their coverage.

Tropical deforestation fires usually spread beyond the conversion regions due to weak incentives and/or low ability to control fires (Cochrane, 2003; Baker and Bunyavejchewin, 2009), so, unlike Kloster et al. (2010), we do not limit the post-fire areas due to deforestation in land-type conversion regions. In CLM4 (Oleson et al., 2010; P. E. Thornton, personal communication, 2011), the carbon and nitrogen loss in the tree-reduced region is distributed into a wood production pool with a residence time of $100 \mathrm{yr}$, a paper production pool with a residence time of $10 \mathrm{yr}$, and a conversion flux released to the atmosphere immediately; and the fraction assigned to the conversion flux is set to $60 \%$ for tropical trees following Houghton et al. (1983). In conversion regions, the maximum fire carbon emissions are assumed to be $80 \%$ of the total conversion flux as Kloster et al. (2010). To reach the maximum fire carbon emissions in a conversion region requires burning this region about twice $(80 \% \times 60 \% \approx 0.3+(1-0.3) \times 0.3)$ when we set combustion completeness factor to 0.3 for stem (the mean of $0.2-0.4$ used in van der Werf et al., 2010). Therefore, when the burned area calculated from Eq. (5) is no more than twice the tree-reduced area, we assume no escaped fires outside the land-type conversion region, and the fire-related fraction of the total conversion flux is estimated as $\frac{A_{\mathrm{b}} / A_{\mathrm{g}}}{2 D} \times 0.8$. Otherwise, $80 \%$ of the total conversion flux is assumed to be fire carbon emissions, and the biomass combustion and vegetation mortality outside the tree-reduced regions with an area fraction of $\frac{A_{b}}{A_{g}}-2 D$ are set the same as Li et al. (2012a). Emission of trace gases and aerosols are estimated using the emission factors in Tables 3 and 4 of Li et al. (2012a).

\subsection{Peat fires}

The burned area due to peat fires is given as

$A_{\mathrm{b}}=c f_{\text {cli, } \mathrm{p}} f_{\text {peat }}\left(1-f_{\text {sat }}\right) A_{\mathrm{g}}$,

where the constant $c$ ((time step $\left.)^{-1}\right)$ is derived using an inverse method (see Sect. 4 ), and $f_{\text {cli, }}$ represents the effect of climate on the burned area; $f_{\text {peat }}$ is the fractional coverage of peatland in the grid cell; and $f_{\text {sat }}$ is the fraction of the grid cell with a water table at the surface or higher.

The combustion of tropical peatland is strongly controlled by climate (Field et al., 2009; Page et al., 2009). Similar to deforestation fires, peat fires occur late in the dry season, which represents the long-term memory of peat soil to the wet-season climate (Page et al., 2009). Peat fires are ground fires. Different from deforestation fires, peat fires may persist for a very long time and are not so sensitive to intraseasonal 
and real-time precipitation (Cochrane and Ryan, 2009). Accordingly, we set $f_{\text {cli, }}$ as a function of long-term precipitation $P_{60 \mathrm{~d}}$,

$f_{\text {cli, } \mathrm{p}}=\max \left[0, \min \left(1, \frac{4-P_{60 \mathrm{~d}}}{4}\right)\right]^{2}$,

and neglect the effects of intraseasonal and real-time precipitation on peat fires. In southern Central Kalimantan, Borneo, Indonesia, Eq. (9) simulates an obvious peak in 1997 and a smaller one in 2002 during 1997-2004, consistent with the observed interannual variability of peat fires (Page et al., 2009); in 1997, Eq. (9) peaks in September/October, consistent with the observed seasonality of peat fires (http: //en.wikipedia.org/wiki/1997_Southeast_Asian_haze).

In boreal peatlands, fires generally do not occur in frozen peat, and drier and/or warmer conditions are likely to increase the risk of peat burning (Turetsky et al., 2004). Thus, we set $f_{\text {cli, } \mathrm{p}}$ as

$f_{\text {cli, } \mathrm{p}}=\exp \left(-\pi \frac{\theta_{17 \mathrm{~cm}}}{0.3}\right) \cdot \max \left[0, \min \left(1, \frac{T_{17 \mathrm{~cm}}-T_{\mathrm{f}}}{10}\right)\right]$

where $\theta_{17 \mathrm{~cm}}$ and $T_{17 \mathrm{~cm}}$ are the soil wetness and soil temperature of the top $17 \mathrm{~cm} ; T_{\mathrm{f}}=273.15 \mathrm{~K}$ is the freezing temperature. A total of $17 \mathrm{~cm}$ are the observed maximum burned depth of boreal bogs (Benscoter et al., 2011), and also close to the maximum burned depth for boreal organic soil $(15 \mathrm{~cm})$ used in van der Werf et al. (2010).

Peat fires lead to peat combustion and the combustion and mortality of vegetation in peatlands. For tropical peat fires, based on Page et al. (2002), about $18 \%$ of the peat soil carbon is emitted with $1 \%$ of peatland burned (ref: about $6 \%$ of the peat carbon loss from store caused by $33.9 \%$ of the peatland burned, $6 \% / 33.9 \%=18 \%$ ). Correspondingly, carbon emissions due to peat combustion $\left.\left(\mathrm{g} \mathrm{C} \mathrm{m}^{-2} \text { (time step) }\right)^{-1}\right)$ are set as the product of 0.18 , burned area fraction of peat fire ((time step $\left.)^{-1}\right)$, and soil organic carbon $\left(\mathrm{g} \mathrm{C} \mathrm{m}^{-2}\right)$. For boreal peat fires, the carbon emissions due to peat combustion are set as $2.2 \mathrm{kgC}$ per $\mathrm{m}^{2}$ peat fire area, based on Turetsky and Wieder (2001). The emissions of trace gases and aerosols due to peat combustion are estimated based on the emission factors of peat fires from van der Werf et al. (2010) (Table 3). The biomass combustion and related emissions of trace gases and aerosols, and vegetation mortality in post-fire peatlands are set similar to those for tree, grass, and shrub PFTs in Li et al. (2012a).

\subsection{Socioeconomic influence on fires}

Humans influence fire counts not only by adding ignition sources (intentionally and accidentally), but also by suppressing both anthropogenic and natural fires. Earlier studies (Arora and Boer, 2005; Pechony and Shindell, 2009; Thonicke et al., 2010; Kloster et al., 2010; Li et al., 2012a, b) only considered the impact of population density on fire occurrence. In reality, the economic conditions may also affect fire
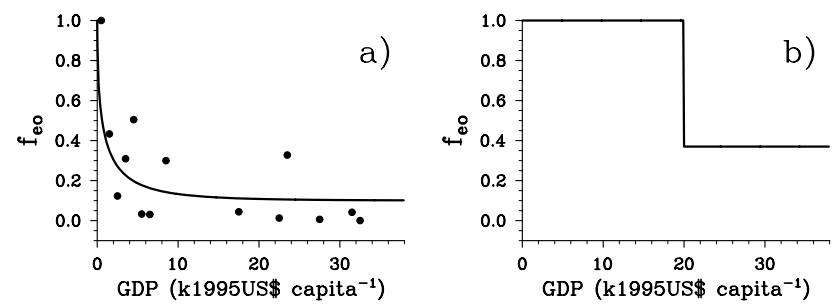

Fig. 5. Effect of economic situation on fire occurrence, $f_{\mathrm{eo}}$, for (a) grass and shrub PFTs and (b) tree PFTs (lines). In shrub- and grassdominated regions (fractional coverage of shrub and grass PFTs $>50 \%$ ), 2001-2004 average $0.5^{\circ}$ MODIS fire counts are partitioned over $1 \mathrm{k} 1995 \mathrm{US}$ capita $^{-1}$ GDP bins. Black circles in (a) indicate the (normalized) average fire counts in bins with sample size $>5$. Goodness of fit is $R^{2}=0.73(n=14) . f_{\text {eo }}$ in (b) reproduces that the MODIS fire count in tree-dominated regions of GDP $\geq 20 \mathrm{k} 1995 \mathrm{US}_{\mathrm{capita}^{-1}}$ is 0.39 of that in other treedominated regions.

regimes (Chuvieco et al., 2008; Aldersley et al., 2011). In the present study, the parameterizations of economic impact on fire occurrence and socioeconomic impact on fire spread are added to Li et al. (2012a, b) for non-peat fires outside cropland and tropical closed forests. For scarcely populated regions $\left(D_{\mathrm{p}} \leq 0.1\right.$ person $\left.\mathrm{km}^{-2}\right)$, e.g., northern Australia and parts of the boreal forest, fires are usually regarded as posing a very low risk to human life and infrastructure, no matter how well developed the country, so the fire management is very limited (Mollicone et al., 2006; Gill et al., 2009; Le Page et al., 2010a). Thus, we assume no economic influence on fire occurring and socioeconomic influence on fire spreading in regions of $D_{\mathrm{p}} \leq 0.1$ person $\mathrm{km}^{-2}$. In regions of $D_{\mathrm{p}}>0.1$ person $\mathrm{km}^{-2}$, we parameterize the socioeconomic influence on fires as follows.

For shrub and grass PFTs, the economic influence on fire occurrence is parameterized as

$f_{\mathrm{eo}}=0.1+0.9 \times \exp \left[-\pi\left(\frac{\mathrm{GDP}}{8}\right)^{0.5}\right]$,

which captures $73 \%$ of the observed MODIS fire counts with variable GDP in regions where shrub and grass PFTs are dominant (fractional coverage of shrub and grass PFTs $>50 \%$ ) (Fig. 5a). In regions outside tropical closed forests and dominated by trees (fractional coverage of tree PFTs $>50 \%$ ), we could not find a skillful continuous function to fit the economic impact. Therefore, we divide the MODIS fire counts into only two bins (GDP $\geq 20 \mathrm{k} 1995{\mathrm{US} \$ \text { capita }^{-1} \text {, and }}^{-1}$ GDP $<20 \mathrm{k} 1995 \mathrm{US} \mathrm{capita}^{-1}$ ) and parameterize the economic influence on fire occurring for tree PFTs as

$f_{\mathrm{eo}}=\left\{\begin{array}{cc}0.39, & \text { GDP } \geq 20 \\ 1 & \text { GDP }<20\end{array}\right.$

to reproduce that the MODIS fire count in tree-dominated regions of GDP $\geq 20 \mathrm{k} 1995 \mathrm{US}_{\text {capita }}{ }^{-1}$ is $39 \%$ of that in 
other tree-dominated regions (Fig. 5b). Eqs. (11) and (12) reflect that more developed countries are better at fire detection and fuel management and thus have superior fire suppression. Moreover, Fig. 5 shows the weaker impact of economic conditions on fires for tree PFTs compared with that for grass and shrub PFTs. It is probably because the tree canopy generally conceals surface fires (the most common fire type) better and the tree trunks make fuel management more difficult, which does not vary much with regional economic situations.

The firefighting capacity, which depends on socioeconomic conditions, affects the fire spread area. Due to a lack of observations, we consider the socioeconomic impact on the average burned area of a fire rather than separate fire spread rate and fire duration. The socioeconomic effect on fire spread area is given as

$F_{\mathrm{se}}=F_{\mathrm{d}} F_{\mathrm{e}}$

where $F_{\mathrm{d}}$ and $F_{\mathrm{e}}$ are effects of the demographic and economic conditions on the average spread area of a fire, and are derived in a similar way to Eqs. (3) and (4).

For shrub and grass PFTs, the demographic impact is

$F_{\mathrm{d}}=0.2+0.8 \times \exp \left[-\pi\left(\frac{D_{\mathrm{p}}}{450}\right)^{0.5}\right]$,

and the economic impact factor is

$F_{\mathrm{e}}=0.2+0.8 \times \exp \left(-\pi \frac{\mathrm{GDP}}{7}\right)$

(Fig. 6a and b). For tree PFTs outside tropical closed forests, the demographic and economic impact factors are given as

$F_{\mathrm{d}}=0.4+0.6 \times \exp \left(-\pi \frac{D_{\mathrm{p}}}{125}\right)$

and

$F_{\mathrm{e}}=\left\{\begin{array}{c}0.62, \quad \text { GDP }>20 \\ 0.83,8<\mathrm{GDP} \leq 20 \\ 1, \quad \text { GDP } \leq 8\end{array}\right.$

(Fig. 7a and b). Eqs. (14)-(17) reflect that more developed and more densely populated regions have a higher firefighting capability.

\subsection{Other minor modifications}

First, the effect of temperature on fire occurrence is taken into account to improve the fire seasonality in boreal regions, which is given as

$f_{T}=\max \left[0, \min \left(1, \frac{T+10}{10}\right)\right]$.

This is consistent with the fact that temperature is the main constraint for fire occurrence when temperature is below freezing, and fire generally does not occur when the temperature is less than $-10^{\circ} \mathrm{C}$ (Chen and Chen, 2000; Aldersley et al., 2011). Thonicke et al. (2001) also used freezing
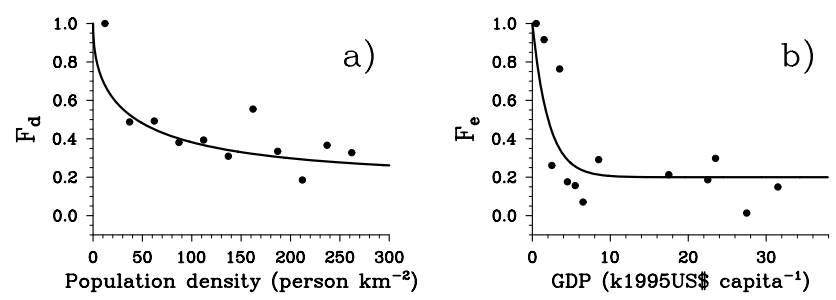

Fig. 6. Effects of (a) demographic situation $F_{\mathrm{d}}$ and (b) economic situations $F_{\mathrm{e}}$ on average burned area of a fire (lines). In shrub- and grass-dominated regions, we partition average burned area of a fire (derived from 2001-2004 GFED3 burned area and MODIS fire counts at $0.5^{\circ}$ spatial resolution) divided by $F_{\mathrm{e}}$ (i.e., $a_{\mathrm{MODIS}, \mathrm{GFED} 3} / F_{\mathrm{e}}$ ) over 25 person $\mathrm{km}^{-2}$ population density bins, and average burned area per fire divided by $F_{\mathrm{d}}$ (i.e.,

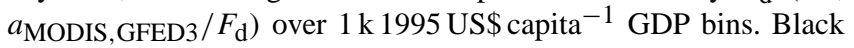
circles indicate the (normalized) average in bins with sample size $>5$. Goodness of fit is $R^{2}=0.71(n=13)$ in (a) and $R^{2}=0.81$ $(n=11)$ in (b).
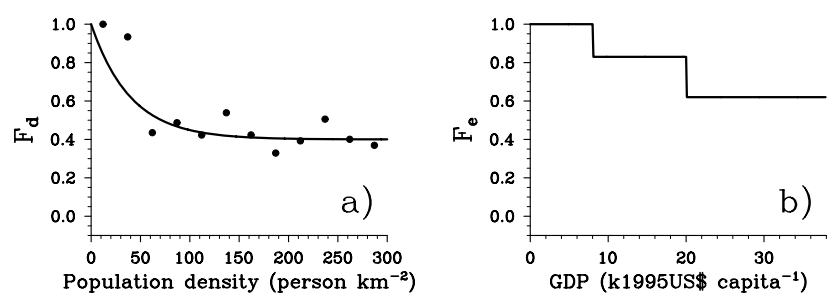

Fig. 7. Same as Fig. 6, but for tree-dominated regions outside tropical closed forests. Goodness of fit is $R^{2}=0.43(n=9)$ in (a). $F_{\mathrm{e}}$ in (b) reproduces that $a_{\mathrm{MODIS}, \mathrm{GFED}} / F_{\mathrm{d}}$ in tree-dominated regions of

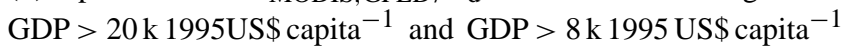
is 0.62 and 0.83 of that in other tree-dominated regions.

temperature as the upper temperature threshold for fire occurrence. Second, due to introducing the effects of economic conditions and temperature on fire occurrence, constant $a$ in Eq. (5) of Li et al. (2012a, b), which is the number of potential ignition sources per person per month, is changed to 0.0035 (count person ${ }^{-1}$ month $^{-1}$ ) according to the method introduced in Appendix A of Li et al. (2012a). After adding the influence of economic conditions and temperature on fire occurrence, the explained variance of observed fire counts is improved to $82 \%$ from original $67 \%$ for the sample used in Appendix A of Li et al. (2012a). When the socioeconomic influence on the average spread area for a fire is introduced, the meaning of $u_{\max }$ in Eq. (14) of Li et al. (2012a, b) is changed to the expected maximum average fire spread rate not only when wind speed and fuel wetness are optimal for fire spread but also when there is no anthropogenic suppression. Correspondingly, $u_{\max }$ increases to $0.50 \mathrm{~m} \mathrm{~s}^{-1}$ for grass PFTs, $0.45 \mathrm{~m} \mathrm{~s}^{-1}$ for shrub PFTs, $0.42 \mathrm{~m} \mathrm{~s}^{-1}$ for needleleaf tree PFTs, and $0.39 \mathrm{~m} \mathrm{~s}^{-1}$ for other tree PFTs. 


\section{Application and CESM1 simulations}

CESM is a global coupled Earth system model hosted at the National Center for Atmospheric Research (NCAR). CESM version 1 (CESM1) and its precursor CCSMs (Community Climate System Models) are used for Intergovernmental Panel on Climate Change (IPCC, http://www.ipcc. $\mathrm{ch} /$ ) global change research. CESM1 provides state-of-theart computer simulations of Earth's past, present, and future climate states and is a platform to quantify and understand various Earth system processes and interactions. It consists of five geophysical models: atmosphere model (atm), ocean model (ocn), land model (lnd), land-ice model (glc), and sea-ice model (ice), plus a coupler that coordinates the five models and passes information between them (Vertenstein et al., 2012). Each model may have "active", "data", "dead", or "stub" component version allowing for a variety of "plug and play" combinations. The active (dynamical) components (CAM5, POP2, CLM4, CISM, or CICE4) are generally fully prognostic, and are state-ofthe-art climate prediction and analysis tools. Because the active models are expensive to run, data models that cycle input data are included for model parameterization development, testing, and spin-up. The dead components exist only to support technical system testing. Stub components exist only to satisfy interface requirements when the component is not needed for the model configuration. A detailed description of CESM1 and its code can be found on its home page http://www.cesm.ucar.edu/index.html. Presentations in the CESM annual workshops (http://www.cesm. ucar.edu/events/workshops.html) and the CESM1 special issue in the Journal of Climate (http://journals.ametsoc.org/ page/CCSM4/CESM1) showed that CESM1 can broadly reproduce the observed mean and variability of many primary variables.

In CESM1, the fire dynamics module operates within the CLM4 carbon/nitrogen biogeochemistry model. The CLM4 succeeds CLM3.5 with updates to the soil hydrology, soil thermodynamics, snow dynamics, albedo parameters, the land surface type dataset, the river transport models, capability to apply transient land use and land cover change (LULCC) including wood harvesting, a new urban canyon model, and several other minor modifications (Oleson et al., 2010; Lawrence et al., 2011). The modeling of $\mathrm{C} / \mathrm{N}$ dynamics in CLM4 is based on the Biome-BGC model, which estimates the states and fluxes of carbon and nitrogen for vegetation, litter, and soil organic matter, and the associated exchange with the atmosphere (Thornton et al., 2007; P. E. Thornton, personal communication, 2011). To generalize plant function to the global scale, CLM4 represents vegetation as 17 plant functional types (PFTs): 8 tree PFTs, 3 shrub PFTs, 3 grass PFTs, 2 crop PFTs, and bare soil PFT (Table 2).

When the new fire model is applied in CESM1, parameters $a_{1}$ in Eq. (1) and $c$ in Eq. (8) are estimated using an inverse method, similar to the estimation of the propensity of people to produce ignition events in SPITFIRE (Thonicke et al., 2010). Specifically, they are derived by matching simulations with the following references: the long-term average contribution of cropland fires was $4.7 \%$ of the total global burned area (van der Werf et al., 2010); about 2.4 Mha of peatland were burned over Indonesia in 1997 (Page et al., 2002); the average burned area of peat fires in Western Canada (Northwest Territories, Alberta, British Columbia, Saskatchewan)

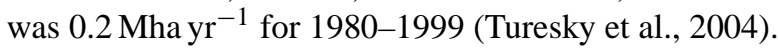

CESM1 supports various component sets. A component set is a particular mix of six components: one component version ("active", "data", "dead", or "stub") from each model (atm, ocn, lnd, glc, and ice) plus the coupler, along with component-specific simulation setting. In the present study, the transient component set I20TRCN is used to evaluate the new fire parameterization. It uses the "data" version for atmosphere model, "active" version for land model (i.e., CLM4 with carbon/nitrogen biogeochemistry), and "stub" version for ocean, sea-ice, and land-ice models, plus the coupler; and provides a 1850-2004 transient simulation forced by 1850 2004 transient time-varying $\mathrm{CO}_{2}$ concentration, nitrogen and aerosol deposition, and land use and land cover changes (wood harvesting included). The transient run starts from an equilibrium (spun-up) state of CLM4 with carbon/nitrogen biogeochemistry forced by the cycling $25 \mathrm{yr}$ (1948-1972) of the Qian et al. (2006) atmospheric observations, land cover in $1850, \mathrm{CO}_{2}$ concentration in 1850, and nitrogen and aerosol deposition in 1850 (Vertenstein et al., 2012). The "data" atmosphere model is obtained by cycling $25 \mathrm{yr}$ (1948-1972) Qian et al. (2006) and bias-corrected relative humidity for 1850-1949 followed by the full time series for the years 1950-2004, and $3 \mathrm{~h}$ lightning data, which are derived from NASA LIS/OTD $2 \mathrm{~h}$ climatological lightning data before May 1995 and NASA LIS/OTD daily lightning time series and the $2 \mathrm{~h}$ climatological lightning data from May 1995 to December 2004. Other input data include the annual 1850 2004 population density that is obtained by temporal linear interpolation of the data from HYDEv3.1 (prior to 1990) and GPWv3 (since 1990), the present-day GDP data and peat map. The simulations are run globally at a $1.9^{\circ} \times 2.5^{\circ}$ spatial resolution with a half-hourly temporal resolution. The input data are regridded to match the requirements of the CESM1 run. In I20TRCN run, $a_{1}=0.56 \mathrm{~h}^{-1}$, and $c=8.2 \times 10^{-4} \mathrm{~h}^{-1}$ for tropical peat fires and $c=2.2 \times 10^{-5} \mathrm{~h}^{-1}$ for boreal peat fires. Moreover, in the present study, the climatological peak month of agricultural fires from van der Werf et al. (2010) is used to specify the month when cropland fires may occur.

\section{Evaluation of fire simulations}

The CESM1 simulations with the fire parameterization introduced in Sect. 3 (Mod-new) are evaluated using the GFED3 fire product. Performance of the fire parameterizations is 
assessed by evaluating the simulations of burned area and fire carbon emissions (two primary fire variables in ESMs). Burned area not only determines the fire carbon emissions (an important item for the calculation of land-atmosphere net carbon exchange), but also influences other carbon/nitrogen fluxes and pools as well as the vegetation composition and structure. The evaluation period is 1997-2004, which is the common period between GFED3 and the simulations. In addition, Mod-new is compared against CESM1 simulations with its current fire parameterization (a modified version of Glob-FIRM) (Mod-old) and modified CTEMFIRE (Mod-CTEM). The code and description for the current fire parameterization in CESM1 can be obtained from http://www.cesm.ucar.edu/models/cesm1.0/; the modified CTEM-FIRE was described by Kloster et al. (2010) in detail.

\subsection{Burned area}

Figure 8a shows the GFED3 and simulated global total of annual burned area averaged over 1997-2004. The mean annual global burned area with the new fire module is $337 \mathrm{Mha} \mathrm{yr}^{-1}$, close to the GFED3 (380 $\mathrm{Mha} \mathrm{yr}^{-1}$ ). Relative to GFED3, both Mod-old (167 $\mathrm{Mha} \mathrm{yr}^{-1}$ ) and Mod-CTEM $\left(178 \mathrm{Mha} \mathrm{yr}^{-1}\right)$ tend to underestimate the global burned area by at least $50 \%$. With the new fire scheme, the contributions of four components to the 1997-2004 average global total are as follows: $4.7 \%$ from agricultural fires, $2.8 \%$ from tropical deforestation and degradation fires, $92.1 \%$ from nonpeat fires outside cropland and tropical closed forests, and $0.4 \%$ from peat fires. The estimated burned area in cropland is $12.4 \%$ with the old fire scheme, which does not distinguish between agricultural fires and non-agricultural fires, whereas the modified CTEM-FIRE assumes no fires in cropland. The old one does not model deforestation fires explicitly, and the modified CTEM-FIRE simulates the contribution of global deforestation fires as $6.3 \%$. Both old fire scheme and modified CTEM-FIRE do not include peat fires.

Figure $8 \mathrm{~b}$ shows the spatial dispersion/heterogeneity of the annual burned area fraction on the global land surface grids at $1.9^{\circ}$ (lat) $\times 2.5^{\circ}$ (long) spatial resolution, which is quantified using the coefficient of variation, $\mathrm{CV}$ (the ratio of the standard deviation to the mean). The CV for Mod-new is 3.5, which is closer to GFED3 $(\mathrm{CV}=4.5)$ than Mod-old $(\mathrm{CV}=2.7)$ and Mod-CTEM $(\mathrm{CV}=2.3)$, although all three schemes underestimate the spatial heterogeneity of the annual burned area fraction.

Mod-new also reproduces the main features of the global spatial distribution of the annual burned area fraction (Fig. 9). It correctly captures the high burned area fraction in tropical savannas, the moderate fraction in northern Eurasia, and the low fraction in deserts due to low fuel availability and in humid forests due to low fuel combustibility. Mod-new shows an improved simulation of the spatial pattern relative to the Mod-old and Mod-CTEM, especially in the tropics. The
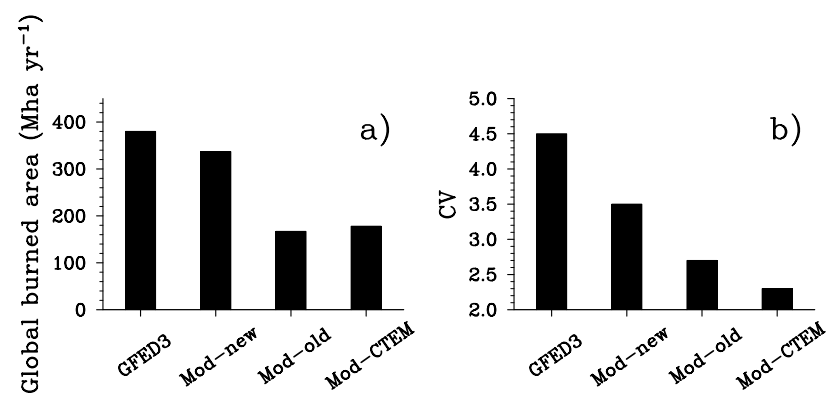

Fig. 8. 1997-2004 average (a) global annual burned area and (b) spatial dispersion of annual burned area fraction on global land surface grids quantified by coefficient of variation CV from GFED3 and CESM1 simulations with the fire parameterization introduced in Sect. 3 (Mod-new), CESM1 current fire parameterization (Modold) and modified CTEM-FIRE (Mod-CTEM).

Table 4. Annual burned area (Mha) for Africa (NHAF: Northern Hemisphere Africa; SHAF: Southern Hemisphere Africa) from GFED3 and CESM1 simulations with the fire parameterization introduced in Sect. 3 (Mod-new), CESM1 current fire parameterization (Mod-old) and modified CTEM-FIRE (Mod-CTEM).

\begin{tabular}{lcccc}
\hline & GFED3 & Mod-new & Mod-old & Mod-CTEM \\
\hline NHAF & 134 & 116 & 18 & 24 \\
SHAF & 124 & 83 & 38 & 45 \\
\hline
\end{tabular}

global spatial correlation between GFED3 and the simulations increases from Cor $=0.23$ for Mod-old and Cor $=0.44$ for Mod-new to Cor $=0.69$ for Mod-new.

The African continent contains the majority of global burned area, contributing $68 \%$ of global total amount for 1997-2004 based on GFED3 (134 Mha yr ${ }^{-1}$ for Northern Hemisphere Africa and $124 \mathrm{Mha} \mathrm{yr}^{-1}$ for Southern Hemisphere Africa). All of the simulations have a low bias over

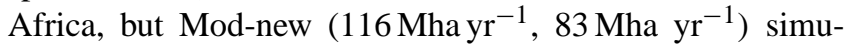
lates the high burned area in Africa better than Mod-old (18 $\mathrm{Mha} \mathrm{yr}^{-1}, 38 \mathrm{Mha} \mathrm{yr}^{-1}$ ) and Mod-CTEM (24 Mha yr ${ }^{-1}$,

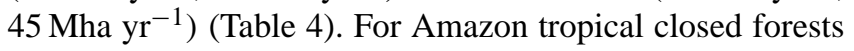
where deforestation and degradation fires are primary, the relative mean squared error (MSE divided by the variance of GFED3 annual burned area fraction) is 0.39 for Mod-new, 0.72 for Mod-old, and 2.72 for Mod-CTEM (Fig. 10), justifying the improved simulation of tropical deforestation fires using the scheme described in Sect. 3.2.

In Southern Hemisphere Africa, almost all of the presentday fires are managed by humans for various purposes, and the fire management is affected by the culture and socioeconomic status (Saarnak, 2001; Hoffmann et al., 2009). The new fire model only captures the primary statistical relationship between fires and population density/GDP on a global scale, and may miss some useful information about the human dimension of fires in the region. This may be 
Annual burned area fraction $\left(\% \mathrm{yr}^{-1}\right)$

GFED3

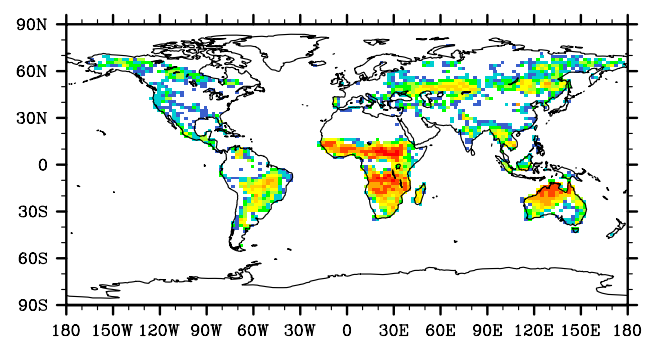

Mod-old (Cor $=\mathbf{0 . 2 3 )}$

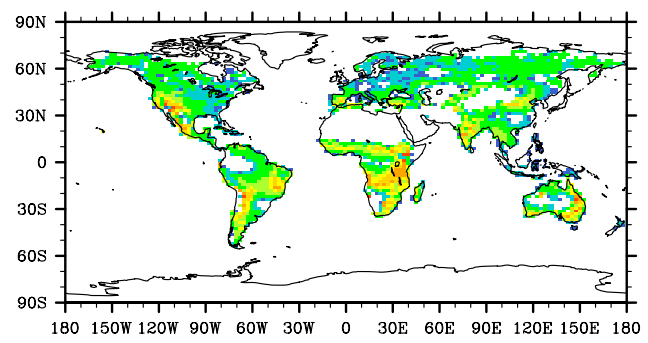

Mod-new (Cor=0.69)

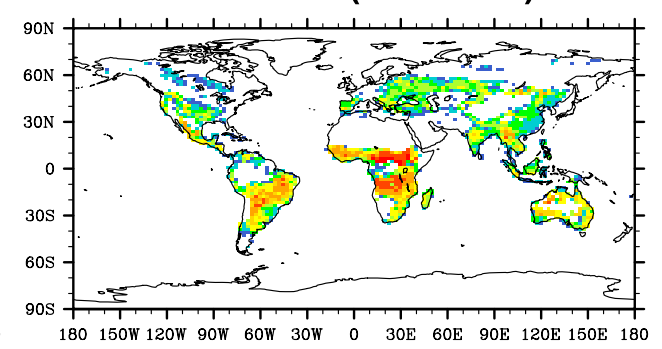

Mod-CTEM (Cor=0.44)

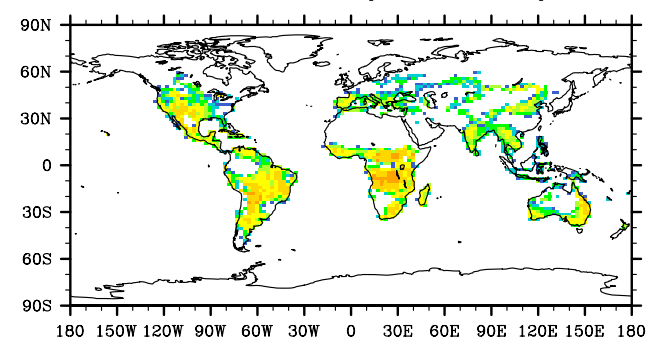

\begin{tabular}{llll|l|l|l|l|l|l|l} 
& 0.1 & 0.2 & 0.5 & 1 & 2 & 5 & 10 & 20 & 50
\end{tabular}

Fig. 9. Spatial distribution of annual burned area fraction averaged over 1997-2004 for GFED3 and CESM1 simulations with different fire parameterizations. The global spatial correlation (Cor) between GFED3 and simulation is also given.
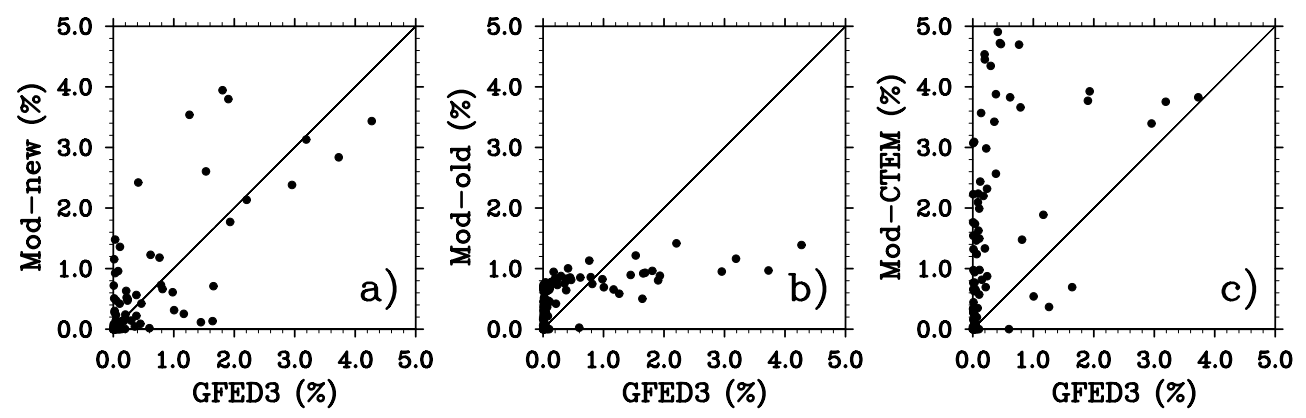

Fig. 10. Comparison of GFED3 and modeled 1997-2004 average annual burned area fraction over Amazon tropical closed forest. The black line depicts the $1: 1$ slope and represents the perfect simulation. Relative mean squared error (MSE divided by the variance of GFED3 annual burned area fraction) is 0.39 for Mod-new, 0.72 for Mod-old and 2.72 for Mod-CTEM.

a reason for the underestimation of burned area in Modnew (Fig. 9, Table 4). In addition, all of the CLM4 simulations underestimate annual burned area fraction in savanna region of northern Australia (Fig. 9, GFED3: $>10 \% \mathrm{yr}^{-1}$, Mod-new: $\sim 2 \% \mathrm{yr}^{-1}$, Mod-old: $\sim 1 \% \mathrm{yr}^{-1}$, Mod-CTEM: $\left.\sim 0.1 \% \mathrm{yr}^{-1}\right)$. The underestimation may be related to the simulation bias of aboveground biomass in CLM4. In savanna region of northern Australia where fuel load is the main limit factor of fire occurrence (van der Werf et al., 2008), simulated aboveground biomass in CLM4 is clearly lower than the reports based on inventory plots and satellite data (William et al., 1998; Saatchi et al., 2011).
It is noted that, in the high-latitudes of North America and eastern Siberia, Mod-new does not substantially improve the fire simulation compared with the other two fire schemes. Mod-new underestimates the burned area as ModCTEM, whereas Mod-old generally overestimates the burned area (Fig. 9). For boreal forests in eastern Siberia and North America, Figs. 9 and 10 in Bonan et al. (2011) showed that CLM4 driven by atmospheric observations obviously underestimated the latent heat flux, especially during the fire season (i.e., summer). The latent heat flux is directly proportional to the water flux output from the land to the atmosphere, so the underestimation of latent heat flux suggests an overestimation of the water retained by the land. The 

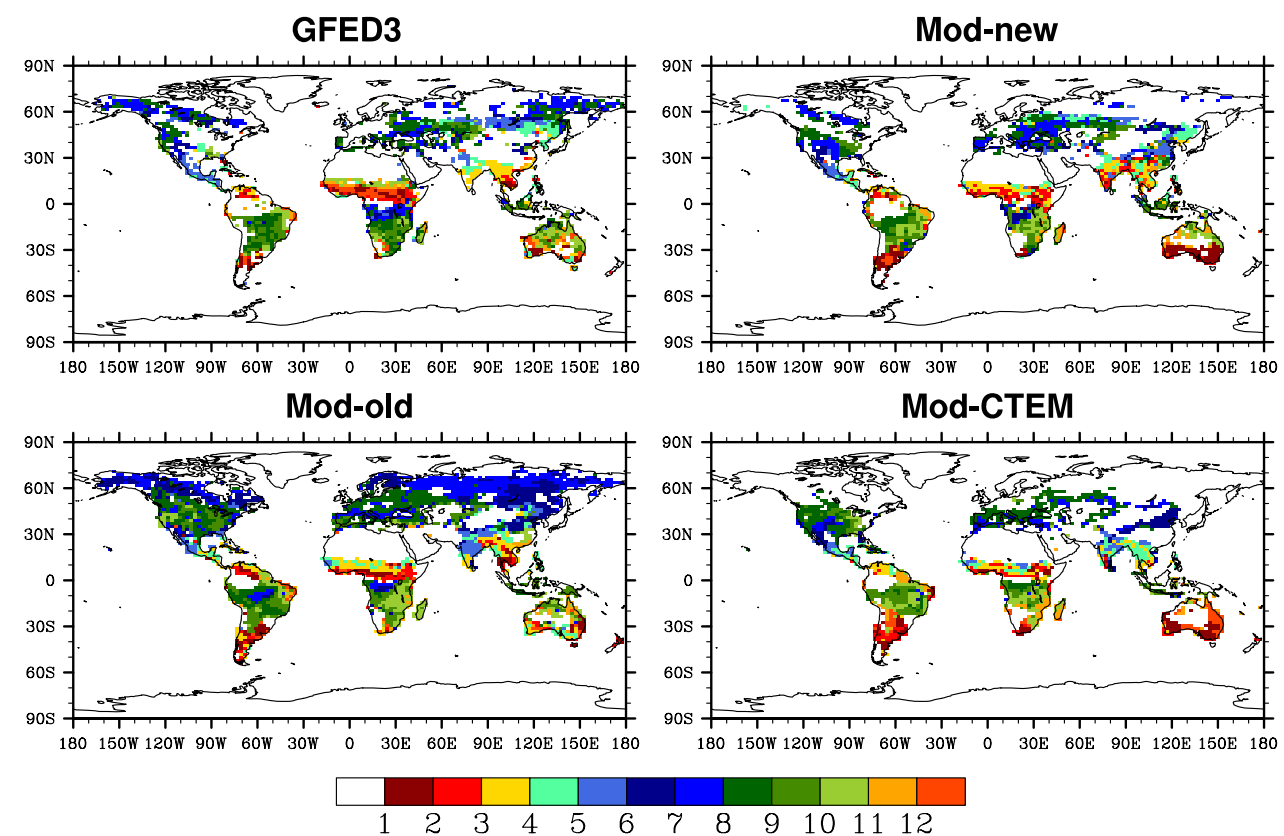

Fig. 11. Same as Fig. 9, but for month of maximum burned area for those areas where burned area fraction $>0.1 \%$.

wet simulation bias of land surface in CLM4 partly explains the underestimation of burned area for Mod-new and ModCTEM in the boreal forests, which is the moisture-limited fire regime region. Underestimation of the biomass due to CLM4's cold and dry simulation bias of soil over boreal tundra (Lawrence et al., 2011) where fuel load is limited factor of fires in summer partly explains the underestimation of the burned area simulated by the Mod-new and Mod-CTEM (H. Lee, personal communication, 2011).

In terms of the fire seasonality, GFED3 and the simulations with all three fire parameterizations produce the same dominant pattern, in which the peak month for burned area varies between the dry season in the tropics and the warm season in extratropical regions (Fig. 11). The transition from tropical to extratropical patterns reflects the effects of precipitation seasonality reinforced by the fact that climatic conditions in high latitudes are generally too cold to burn in winter (Prentice et al., 2011). The introduction of the agricultural fire scheme allows Mod-new to simulate the peak month in eastern China, western Russia, and northern India better than Mod-old and Mod-CTEM. For central and eastern North America (crop-dominated region), Mod-old and ModCTEM overestimate the annual burned area and they also simulate August/September as the peak month rather than April, which is the observed peak month. Moreover, Modnew identifies the peak month of burned area accurately in tropical closed forests, while Mod-CTEM tends to delay the peak month by $1-2$ months in the tropical closed forests of the Southern Hemisphere.

Next, we test the simulated global spatial pattern of fire interannual variability, by using the standard deviation of the annual burned area fraction (Fig. 12). The new fire parameterization and GFED3 show generally similar patterns, e.g., a high interannual variation in the tropical savannas, a medium variation in northeastern China and northwestern Eurasia, and a low variation in the deserts and humid forests. The global spatial correlation between GFED3 and the simulations increases from Cor $=0.14$ for Mod-old and Cor $=0.26$ for Mod-CTEM to Cor $=0.59$ for Mod-new. Figure 13 shows interannual variability of the global burned area from GFED3 and simulations. Mod-new and Mod-CTEM can capture the peak in 1998 shown in GFED3, but they overestimate the decline from 1998 to 1999 as LPX-DGVM (Prentice et al., 2011). Mod-new also reproduces the year-to-year variation from 2000 to 2004. The temporal correlation between Modnew and GFED3 is 0.66, which is higher than the Mod-old (0.08) and Mod-CTEM (0.25).

\subsection{Fire carbon emissions}

The 1997-2004 average global fire carbon emissions simulated by the three fire parameterizations are $2.0 \mathrm{Pg} \mathrm{C} \mathrm{yr}^{-1}$ for Mod-new, 2.0 $\mathrm{Pg} \mathrm{C} \mathrm{yr}^{-1}$ for Mod-CTEM, and 2.3 $\mathrm{PgC} \mathrm{yr}^{-1}$ for Mod-old, close to GFED3 (2.1 $\mathrm{Pg} \mathrm{C} \mathrm{yr}^{-1}$ ) (Fig. 14a). The old scheme and CTEM-FIRE simulate the global total of fire carbon emissions reasonably by arbitrarily setting high combustion completeness of woody biomass in post-fire regions, when their simulated global burned areas are less than half the observed. For tree PFTs, the old scheme sets combustion completeness factor to 0.88 for fine root and live coarse roots and 0.35 for dead coarse roots, which are inconsistent with field observations showing that tree roots in post-fire 


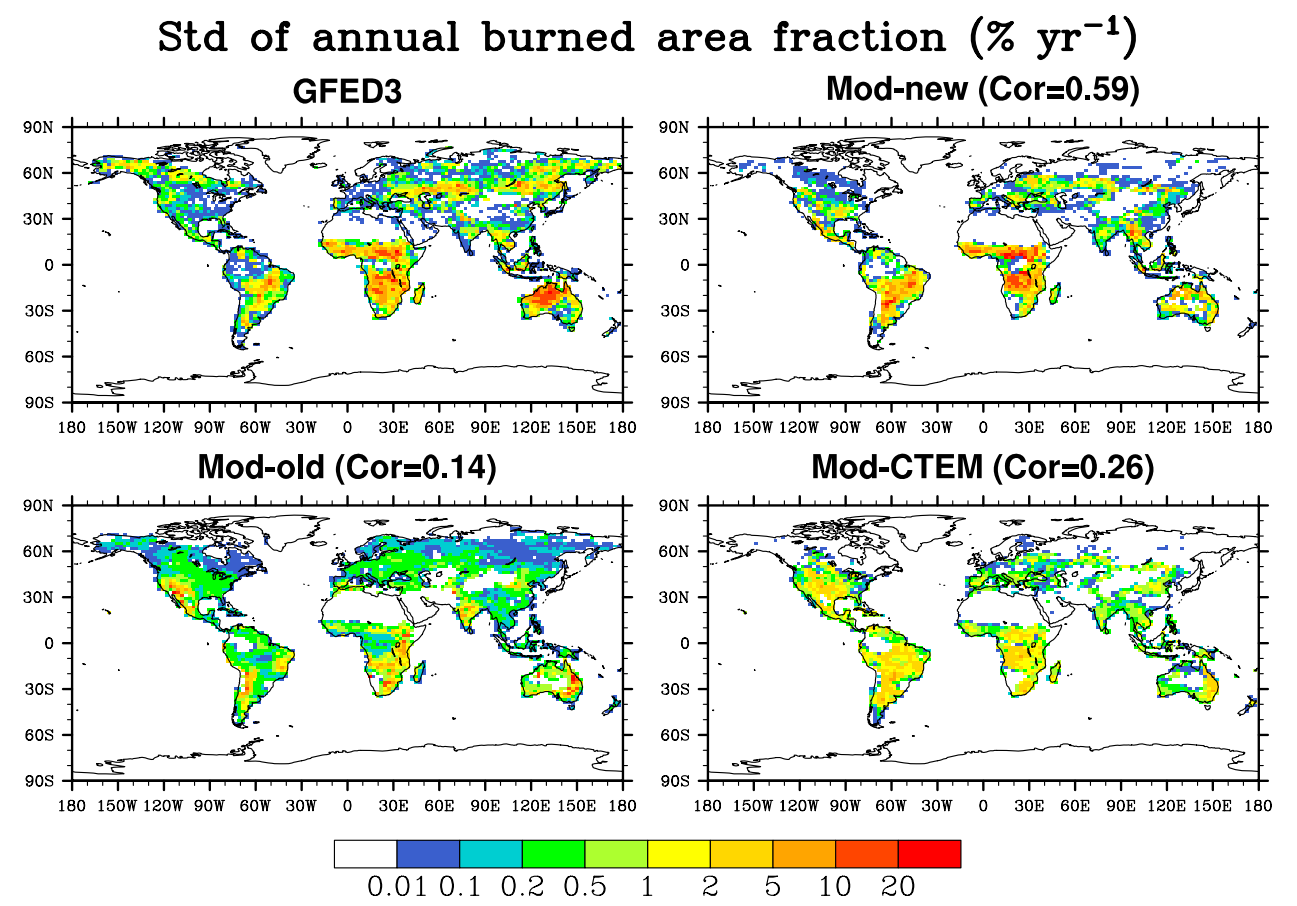

Fig. 12. Same as Fig. 9, but for standard deviation (Std) of annual burned area fraction, which is used as a spatially explicit measure of fire interannual variability.

regions are generally little combusted for carbon emissions to the atmosphere directly due to a lack of oxygen below ground (Zhou and Lu, 2009). Indeed, GFED3 (van der Werf et al., 2010) and the global fire models of Arora and Boer (2006), Kloster et al. (2010), Li et al. (2012a, b), and the present study consider the root mortality and assume no combustion of roots. The modified CTEM-FIRE (Kloster et al., 2010) set combustion completeness factor as 0.5 and $0.5-0.6$ for tree stems and course woody debris, respectively, higher than and on the upper side of combustion completeness factors used by GFED3 (0.2-0.4 for tree stems and 0.4-0.6 for course woody debris). As shown in Fig. 14b, the combustion completeness for Mod-old (13.8 $\mathrm{TgC} \mathrm{Mha}^{-1}$ ) and Mod-CTEM (11.2 $\mathrm{TgC} \mathrm{Mha}^{-1}$ ) are more than double that for GFED3 (5.5 $\mathrm{TgC} \mathrm{Mha}^{-1}$ ), and higher than Mod-new (5.9 $\left.\mathrm{TgC} \mathrm{Mha}^{-1}\right)$.

The new fire scheme also provides fire carbon emissions from different sources (Fig. 15). The 1997-2004 average contributions of the four components to the global total are as follows: $8 \%$ from agricultural fires, $24 \%$ from tropical deforestation and degradation fires, $62 \%$ from non-peat fires outside cropland and tropical closed forests, and $6 \%$ from peat fires (3.8\% from tropical peat fires). The contribution of agricultural waste burning is within the range of earlier assessments: $\sim 16 \%$ from Yevich and Logan (2003) based on government statistics, energy assessments from the World Bank, technical reports and discussions with experts in various research fields in 1985 and 1995; $3 \%$ from satellite-based estimates of van der Werf et al. (2010) for

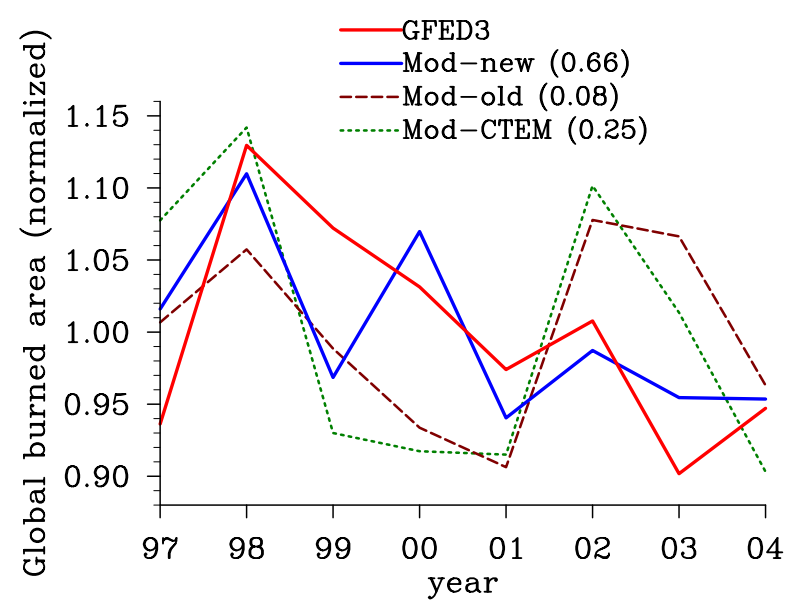

Fig. 13. Annual global burned area normalized by the mean for 1997-2004 from GFED3 and CESM1 simulations with different fire parameterizations. The numbers in brackets denote temporal correlation between GFED3 and simulations.

2001-2009; and $~ 10 \%$ based on MODIS agricultural fire counts (Korontzi et al., 2006), global fire carbon emissions, and assumption of equal emissions for each fire count for 2001-2003 (van der Werf et al., 2010). The contributions of tropical deforestation and degradation fires and peat fires are similar to the satellite-based estimates of van der Werf et al. (2010) for 2001-2009: 20\% from tropical deforestation and degradation fires and $3 \%$ from tropical peat fires. In 


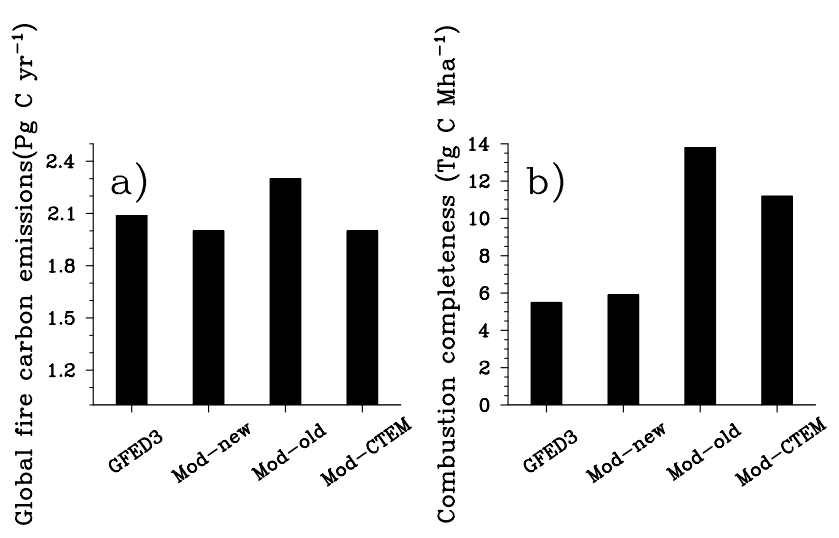

Fig. 14. 1997-2004 average (a) global annual fire carbon emissions and (b) combustion completeness in global post-fire regions.

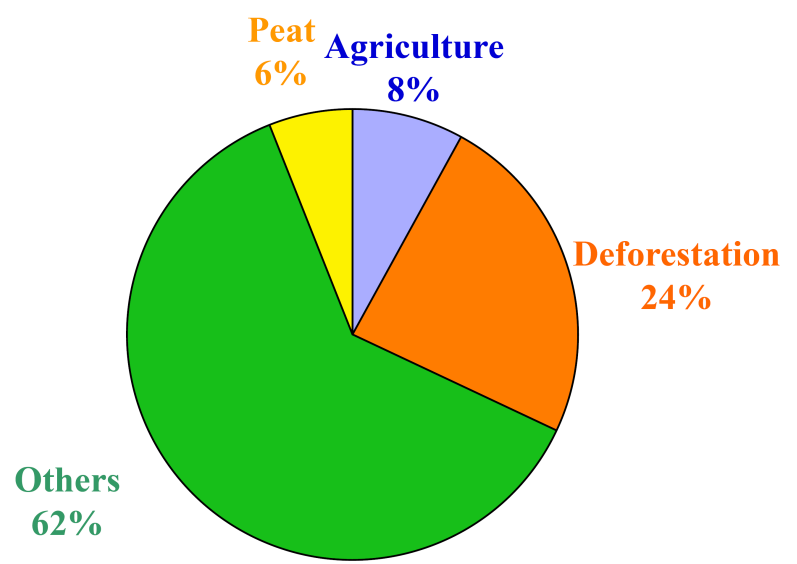

Fig. 15. Contribution of agricultural fires, tropical deforestation and degradation fires, non-peat fires outside cropland and tropical closed forests, and peat fires to 1997-2004 global fire carbon emissions from Mod-new.

Mod-CTEM, the contribution of global deforestation fires is $11 \%$.

For global spatial patterns, the new fire module can reproduce the high carbon emissions in African and South American savannas, the moderate carbon emissions in Canada and around $50^{\circ} \mathrm{N}$ in Eurasia, and the low emissions in desert and frozen soil regions (Fig. 16). Mod-new simulates the emissions in boreal Asia and boreal North America better than Mod-CTEM, although both underestimate the amount of carbon emissions. Mod-old overestimates the number of grid cells with fire carbon emissions. The global spatial correlation between Mod-new and GFED3 is 0.53, higher than that for Mod-old (Cor $=0.39)$ and Mod-CTEM $(\mathrm{Cor}=0.32)$. In addition, all simulations produce similar interannual variability of global fire carbon emissions to GFED3, i.e., peaks in 1997 and 1998 followed by a decline (Fig. 17). The correlation between the simulations and GFED3 is 0.9 for the Modnew and Mod-CTEM and 0.86 for the old fire parameterization.

\section{Direct anthropogenic influence on historical fire regimes}

Concerns have grown about the relative importance of climate change and human influence in shaping historical fire regimes (Marlon et al., 2008; Lehsten et al., 2009; Pechony and Shindell, 2009, 2010; Kloster et al., 2010; Archibald et al., 2012). However, the direct anthropogenic impact (fire ignition and suppression) on global fire regime that varies with climate change remains unclear.

Here we report our results based on CESM1 with the new fire scheme. Simulations with (default) and without direct anthropogenic influence are used to quantify the direct anthropogenic influence on fires. In the simulation without direct anthropogenic influence, the deforestation fires, crop fires, anthropogenic ignitions, anthropogenic suppression, and peat fires due to anthropogenic ignitions are turned off. The fraction of non-peat burned area due to anthropogenic ignitions in the default simulation is applied to separate the anthropogenic peat fires from the natural peat fires.

Figure 18 shows the long-term trends of global burned area and fire carbon emissions from the two simulations. In the default simulation, global burned area and fire carbon emissions declined abruptly after $\sim 1870$, which agrees with the trend of the reconstructed global biomass burning based on sedimentary charcoal records in Marlon et al. (2008), and is supported by the analysis of Antarctic ice-core CO (concentration and isotopic ratios) records (Wang et al., 2010; Prentice, 2010). The reconstructed global biomass burning based on Antarctic ice-core $\mathrm{CH}_{4}$ records (Ferretti et al., 2005 ) showed a pronounced rise after 1870 , which was contrary to Marlon et al. (2008), Wang et al. (2010), and our results. Houwelling et al. (2008) questioned the source of partitioning of historical variation of $\mathrm{CH}_{4}$ emissions of Ferretti et al. (2005). The results of Houwelling et al. (2008) showed that biomass burning was not the main contributor for the sharp upward trend of the $\mathrm{CH}_{4}$ emissions. In addition, estimation in Kloster et al. (2010) based on the modified CTEM-FIRE showed a downward trend in fire carbon emissions between 1900 and 1960, which is weaker than the downward trend in Marlon et al. (2008) and our results, and a clear upward trend during the last three decades of the 20th century, which is not observed in Marlon et al. (2008) and our results. The difference is in part because the increasing anthropogenic suppression on fire spread (accompanying the abrupt growth of population) was not taken into account in the fire model of Kloster et al. (2010), which included only the impact of population on fire occurrence. Different from Marlon et al. (2008), our fire simulations do not show a rise before $\sim 1870$. In CESM's I20TRCN run, artificial atmospheric forcing (cycling 1948-1972 atmospheric observations) is used to drive CLM4 to an equilibrium that is used as the initial data for the transient simulation started from 1850 , and is applied for the 1850-1874 simulation (see Sect. 4). Marlon et al. (2008) pointed out the increasing temperature 
Annual fire carbon emissions ( $\left.\mathrm{g} \mathrm{C} \mathrm{m}^{-2} \mathrm{yr}^{-1}\right)$ GFED3

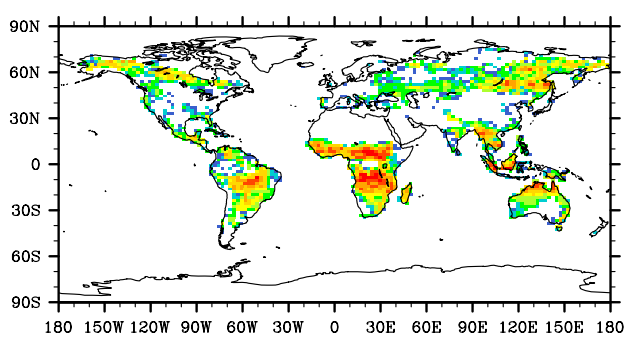

Mod-old (Cor=0.39)
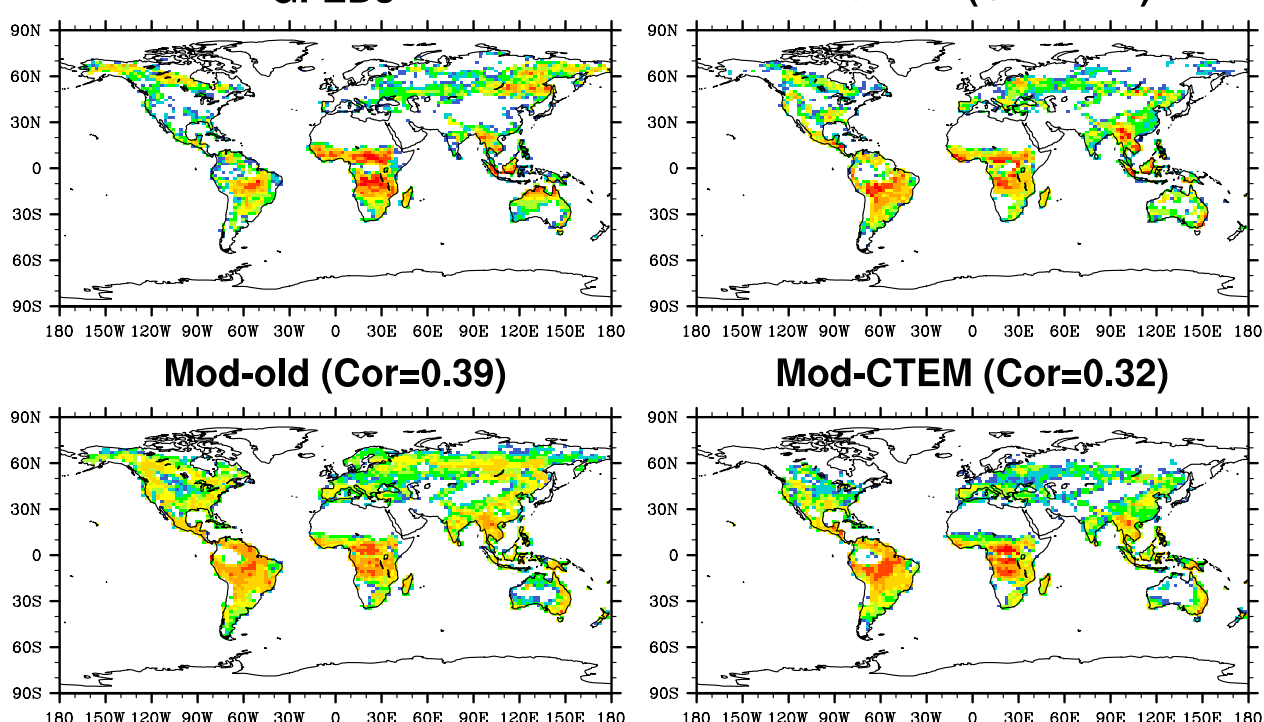

Mod-CTEM (Cor $=\mathbf{0 . 3 2}$ )
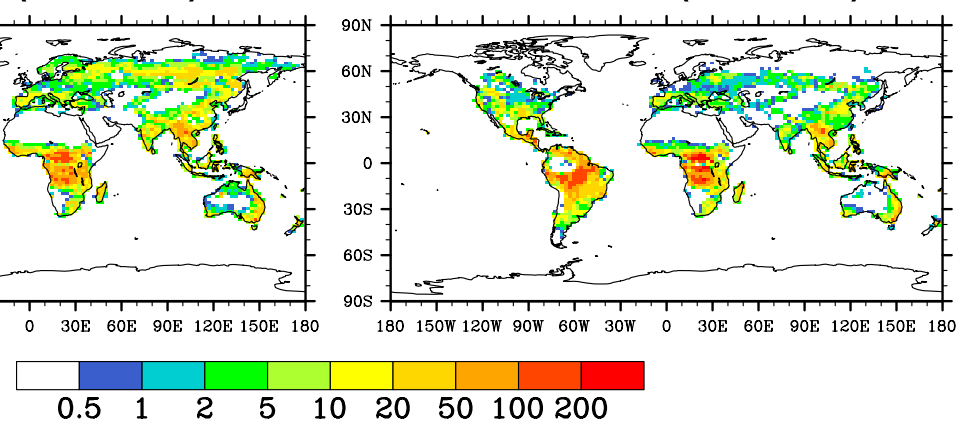

Fig. 16. Same as Fig. 9, but for annual fire carbon emissions.

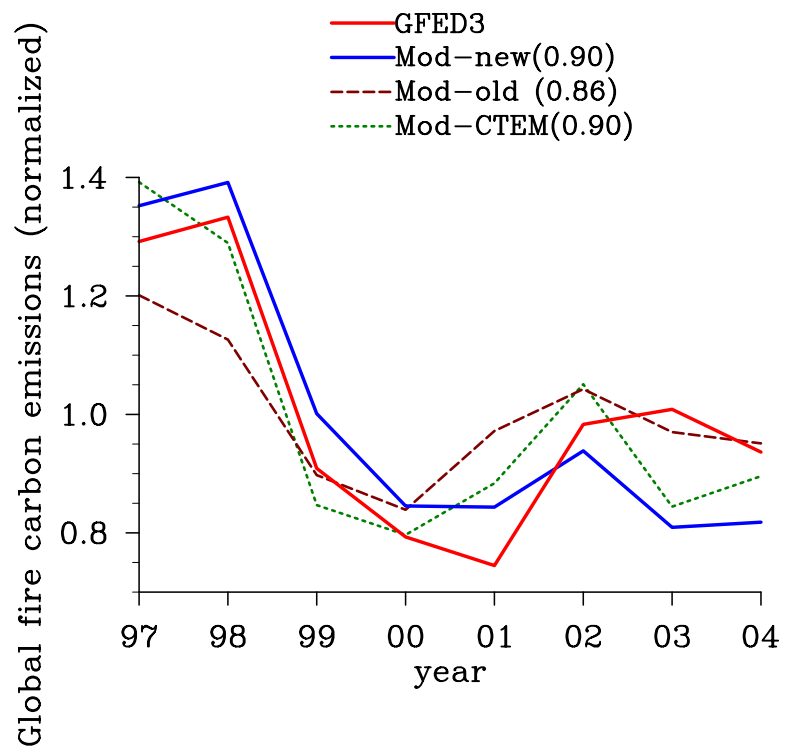

Fig. 17. Same as Fig. 13, but for normalized global fire carbon emissions.

could be one important factor for the biomass-burning increase before $\sim 1870$. Missing the sharp upward trend of temperature in the atmospheric forcing before $\sim 1870$ may partly lead to the loss of the peak at $\sim 1870$ in our fire simulation.
The simulation without direct anthropogenic influence also shows a downward trend in global burned area, but the downward trend in the default simulation is much stronger. Linear trends are $-3.3 \%(10 \mathrm{yr})^{-1}$ and $-1.5 \%(10 \mathrm{yr})^{-1}$ for simulations with and without direct anthropogenic influence, respectively. This suggests that direct anthropogenic influence has been the main driver of long-term trends in global burned area since the middle of the 19th century, consistent with the conclusions of Pechony and Shindell (2010) based on the simulations of fire counts that direct anthropogenic influence on fires has controlled the global fire regime since the Industrial Revolution.

Furthermore, we investigate the main driver for the direct anthropogenic influence on global burned area. In the default simulation, non-peat fires outside croplands and tropical closed forests contribute $95.8 \%$ of global burned area during 1850-2004 and overwhelmingly determine the historical variation pattern of global burned area. Agricultural fires, tropical deforestation fires, and peat fires contribute $3.1 \%, 0.9 \%, 0.2 \%$ of global burned area, respectively, and all of their burned area shows an upward trend during 1850-2004. For non-peat fires outside croplands and tropical closed forests, direct anthropogenic influence on fires is represented by anthropogenic ignition and suppression in our new fire model, and both anthropogenic ignition and suppression are assumed to increase with population density (Li et al., 2012a; Sect. 3.4 of the present study). During 1850-2004, a growth of population in Africa savanna regions, eastern South America, India, central East China, and 
Indochina led to an increase of anthropogenic fire suppression (over the increase of anthropogenic ignition) in these regions, which mainly determines the direct anthropogenic influence on global burned area and significantly affects the long-term trend of global burned area.

For the global total of fire carbon emissions, the simulation without direct anthropogenic influence shows a similar decline to the default simulation (linear trends are $-3.1 \%$ $(10 \mathrm{yr})^{-1}$ and $-2.9 \%(10 \mathrm{yr})^{-1}$ for simulations with and without direct anthropogenic influence), indicating that direct anthropogenic influence on fires is not the main driver of long-term trend in global total of fire carbon emissions. This is supported by the results of numerical experiments from Kloster et al. (2010), who showed that downward trend in global total of fire carbon emissions from 1900 to 1960 was mainly caused by reduced fuels as a consequence of land use and wood harvesting (i.e., the indirect anthropogenic influence on fires). In the default 1850-2004 simulation, non-peat fires outside croplands and tropical closed forests contribute $82.6 \%$ of global fire carbon emissions and show a downward trend; tropical deforestation fires contribute $8.6 \%$ of global fire carbon emissions and show an upward trend. Direct anthropogenic influence leads to a stronger downward trend in carbon emissions due to non-peat fires outside croplands and tropical closed forests, which is almost completely offset by increased carbon emissions due to tropical deforestation fires. Therefore, though direct anthropogenic influence changes the long-term trends of fire carbon emissions in different regions, its impact on the long-term trend of the global total of fire carbon emissions is negligible.

\section{Conclusions and future development}

The new fire parameterization for the Community Earth system model (CESM) contains four components: agricultural fires, non-peat fires outside cropland and tropical closed forests, tropical deforestation fires, and peat fires. The process-based fire parameterization of intermediate complexity described in Li et al. (2012a, b) is revised by mainly adding economic impact on fire occurrence and socioeconomic impact on fire spread, for use by the third component. The new fire scheme has better structure, parameter estimation and mathematical derivation than the current fire scheme in CESM1 (a modified version of Glob-FIRM) and modified CTEM-FIRE (Li et al., 2012a; Paragraph 3 in Sect. 1). Moreover, introducing our parameterization for agricultural fires, tropical deforestation fires, peat fires, and the socioeconomic impact on fires into ESMs allows more realistic representation of fires and the simulation of some extreme air pollution events due to fires.

The new fire scheme is tested in a 1850-2004 transient simulation with the CESM1's land component CLM4, and evaluated against the latest satellite-based GFED3 fire product for 1997-2004. Results show that the new fire scheme
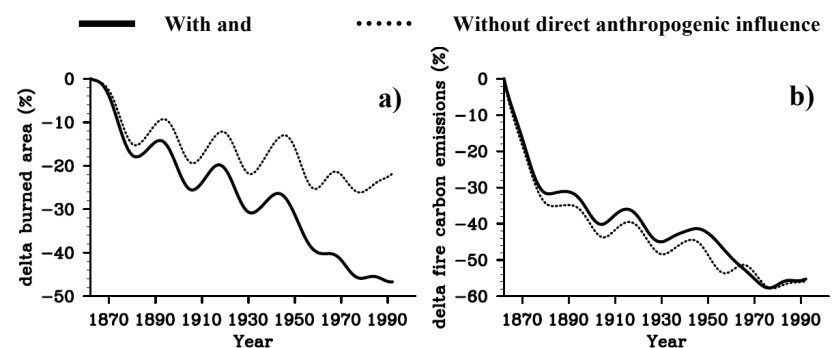

Fig. 18. Historical variation of (a) global burned area and (b) fire carbon emissions in simulations with and without direct anthropogenic influence. $25 \mathrm{yr}$ low-pass filter is used.

reasonably simulates the multi-year burned area, fire seasonality, fire interannual variability, and fire carbon emissions, and performs better than the current fire scheme in CESM1 (a modified version of commonly used Glob-FIRM) and modified CTEM-FIRE.

According to our fire scheme, for 1997-2004, the agricultural biomass burning accounts for $8 \%$ of global fire carbon emissions; the tropical deforestation and degradation fires and global peat fires account for only $2.8 \%$ and $0.4 \%$ of burned area, but $24 \%$ and $6 \%$ of fire carbon emissions; other fires contribute $62 \%$ of global fire carbon emissions. The contributions of fire carbon emissions from various sources are close to previous assessments based on satellite data, government statistics, and other information.

The trends of global fire regimes since the middle 19th century simulated with the new fire parameterization are broadly consistent with earlier reconstructions based on sedimentary charcoal records (Marlon et al., 2008) and Antarctic ice-core CO records (Wang et al., 2010; Prentice, 2010). Based on the new fire scheme, we investigate the direct anthropogenic impact (fire ignition and suppression) on global burned area and fire carbon emissions, by comparing 1850-2004 simulations with and without direct anthropogenic impact. Results show that a clear downward trend since 1850 is mainly caused by the direct anthropogenic impact. For fire carbon emissions, direct anthropogenic influence leads to a stronger downward trend in carbon emissions due to non-peat fires outside croplands and tropical closed forests, which is almost completely offset by the increased carbon emissions due to tropical deforestation fires. Correspondingly, direct anthropogenic influence on the long-term trend of the global total of fire carbon emissions is very small.

The present study contributes many potential applications. First, one major target of fire sciences is to quantify the role of fire in the Earth system on a global scale (Bowman et al., 2009). However, work in this area has been pending (Bowman et al., 2009, 2011; Prentice et al., 2011). Using CESM1 with the new fire model, we can report our estimations by quantifying the disparity between simulations with and without fires. Second, understanding human effects on the Earth system is critical in global change research (IPCC, 2007). 
Fires are an important way that humans affect the Earth system (Bowman et al., 2011). The new fire model with the improved presentation of human influences on fires will help estimate the impact of historical anthropogenic fire regimes on the Earth system and project future impacts with various IPCC emissions and socioeconomic scenarios. Third, the new fire model includes deforestation fires, peat fires, agricultural fires, the socioeconomic impact on fires that have been increasingly appreciated and are related to land use, peatland and agricultural waste management, socioeconomics, and ecology and environment sciences (Page et al., 2002; Turesky et al., 2004; Luiz et al., 2010; Cochrane 2010; Chen et al., 2011; Magi et al., 2012). The new fire model can introduce these multidisciplinary areas of research into the development of Earth system modeling and, at the same time, offer these research fields a platform for numerical experiments and quantitative reports. In addition, the improved representations of anthropogenic impacts on fires and the peat fire scheme are simple, and can be easily applied into other global fire schemes for other ESMs, global climate models, or global ecosystem models.

The present study is an exploratory step toward representing agricultural fires, peat firs, the economic influence on fire occurrence, and the socioeconomic influence on fire spread in global ESMs, and provides an alternative scheme to model deforestation fires. It is still constrained by a lack of data and mechanism analyses on these topics. First, the GDP data used in the present study are the base-year (i.e., 2000) data for the IPCC-SRES that are derived from country-level data (i.e., grid cells in a country have the same GDP values) (van Vuuren et al., 2006). Besides optimizing the estimation of economic impact on fires, the long-term global GDP data with regional disparity in a country, as the model input data, can improve fire simulations. In Figs. 9 and 16, overestimation of burned area fraction and fire carbon emissions in East China is in part because the GDP data do not reflect the much higher economic level in East China than the country average level. Second, many peatlands in Siberia and a peatland in Alaska are classified to other wetland types in GLWD (Lehner and Döll, 2004, a source of our peat map) when compared with Yu et al. (2010). The missing peatland areas may contribute to the underestimation of burned area and fire carbon emissions in these regions (Figs. 9 and 16). Also, previous studies focus on the peat management and peat fires in regions where fire regimes are moisture-limited (i.e., the forests over Canada and Indonesia). The mechanisms of peat fires in boreal tundra are unknown. Third, the new fire module for CESM just parameterizes the deforestation and degradation fires in the tropical closed forests. Mechanism analyses and observations about deforestation and degradation fires in other regions will improve our understanding and help to quantify them in the future. In addition, Randerson et al. (2012) estimate the global contribution of small fires and point out that GFED3 may underestimate burned area and fire carbon emissions by missing small fires. This means
Table A1. List of model variables.

\begin{tabular}{|c|c|c|}
\hline Variable & Description & Unit \\
\hline$a$ & $\begin{array}{l}\text { Potential anthropogenic } \\
\text { ignitions }\end{array}$ & count person ${ }^{-1}$ month $^{-1}$ \\
\hline$A_{\mathrm{b}}$ & Burned area & $\mathrm{km}^{2}{\text { (time step })^{-1}}^{-1}$ \\
\hline$A_{\mathrm{g}}$ & Area of grid cell & $\mathrm{km}^{2}$ \\
\hline$b_{2}$ & Threshold for $P_{60 \mathrm{~d}}$ & $\mathrm{~mm} \mathrm{~d}^{-1}$ \\
\hline$b_{3}$ & Threshold for $P_{10 \mathrm{~d}}$ & $\mathrm{~mm} \mathrm{~d}^{-1}$ \\
\hline$D_{\mathrm{p}}$ & Population density & person $\mathrm{km}^{-2}$ \\
\hline$D$ & Decreased tree coverage & $\mathrm{yr}^{-1}$ \\
\hline$f_{b}$ & Fuel availability factor & - \\
\hline$f_{\text {cli, } \mathrm{d}}$ & $\begin{array}{l}\text { Effect of climate on } \\
\text { deforestation fires }\end{array}$ & - \\
\hline$f_{\text {cli, } \mathrm{p}}$ & $\begin{array}{l}\text { Effect of climate on peatland } \\
\text { burned area }\end{array}$ & - \\
\hline$f_{\text {crop }}$ & Fractional coverage of cropland & - \\
\hline$f_{\mathrm{d}}$ & Effects of population density and & - \\
\hline$f_{\mathrm{e}}$ & GDP on agricultural burned area & - \\
\hline$f_{\mathrm{eo}}$ & $\begin{array}{l}\text { Effect of economic situation on } \\
\text { fire occurrence }\end{array}$ & - \\
\hline$f_{\text {lu }}$ & $\begin{array}{l}\text { Effect of decreases of tree } \\
\text { coverage on burned area }\end{array}$ & - \\
\hline$f_{\text {peat }}$ & Coverage fraction of peatland & - \\
\hline$f_{\mathrm{sat}}$ & $\begin{array}{l}\text { Area fraction with water table } \\
\text { higher/at the surface }\end{array}$ & - \\
\hline$f_{\mathrm{se}}$ & $\begin{array}{l}\text { Socioeconomic effect on burned } \\
\text { area of agricultural fires }\end{array}$ & - \\
\hline$f_{t}$ & $\begin{array}{l}\text { Factor to determine agricultural fire } \\
\text { seasonality }\end{array}$ & - \\
\hline$f_{T}$ & $\begin{array}{l}\text { Effect of temperature on fire } \\
\text { occurrence }\end{array}$ & - \\
\hline$F_{\mathrm{d}}$ & Effects of population density and & - \\
\hline$F_{\mathrm{e}}$ & GDP on average spread area of a fire & - \\
\hline$F_{\mathrm{se}}$ & $\begin{array}{l}\text { Socioeconomic effect on fire spread } \\
\text { area }\end{array}$ & - \\
\hline$D$ & Decreased tree coverage & $\mathrm{yr}^{-1}$ \\
\hline GDP & Gross domestic product & k 1995 US $\$$ capita $^{-1}$ \\
\hline$P_{60 \mathrm{~d}}$ & 60 -day running mean of precipitation & $\mathrm{mm} \mathrm{d}^{-1}$ \\
\hline$P_{10 \mathrm{~d}}$ & 10-day running mean of precipitation & $\mathrm{mmd}^{-1}$ \\
\hline$P$ & Precipitation & $\mathrm{mmd}^{-1}$ \\
\hline$T_{17 \mathrm{~cm}}$ & Soil temperature of the top $17 \mathrm{~cm}$ & $\mathrm{~K}$ \\
\hline$T_{\mathrm{f}}$ & Freezing temperature & $\mathrm{K}$ \\
\hline$T$ & Temperature & $\mathrm{K}$ \\
\hline$u_{\max }$ & Maximum average fire spread rate & $\mathrm{ms}^{-1}$ \\
\hline$\theta_{17 \mathrm{~cm}}$ & Soil wetness of the top $17 \mathrm{~cm}$ & $\mathrm{~mm}^{3} \mathrm{~mm}^{-3}$ \\
\hline
\end{tabular}

that Eqs. (3)-(6) and (14)-(17) could be recalibrated (based on methods in Sect. 3) using the Randerson et al. (2012) data rather than GFED3, and results could be compared.

Acknowledgements. This study is co-supported by the State Key Project for Basic Research Program of China (973) under Grant No. 2010CB951801, the Strategic Priority Research Program of Chinese Academy of China under Grant No. XDA05110201, and the Key Program of National Natural Science Foundation under Grant No. 41005052. We are grateful to X.-D. Zeng and Q.-C. Zeng from Institute of Atmospheric Physics, Chinese Academy of Sciences, L. Giglio from NASA Goddard Space Flight Center, J. T. Randerson from University of California, H. Lee from NCAR, Z. Subin from Princeton University, N. M. Mahowald from Cornell University, and S. Kloster from Max Planck Institute for Meteorology for helpful discussions. We also thank the two anonymous reviewers for their valuable comments and suggestions; and appreciate the Editor A. Arneth's insisting that we elaborate 
the main driver for the direct anthropogenic influence on global burned area, which led us to discover the error in our earlier CESM input data on 1850-2004 population density.

Edited by: A. Arneth

\section{References}

Aldersley, A. Murray, S. J., and Cornell, S. E.: Global and regional analysis of climate and human drivers of wildfire, Sci. Total. Environ., 409, 3472-3481, 2011.

Andreae, M. O. and Merlet, P.: Emission of trace gases and aerosols from biomass burning, Global Biogeochem. Cy., 15, 955-966, 2001.

Archibald, S., Staver, C., and Levin, S. A.: Evolution of humandriven fire regimes in Africa, P. Natl. Acad. Sci. USA, 109, 847852. 2012.

Arora, V. K. and Boer, G. J.: Fire as an interactive component of dynamic vegetation models, J. Geophys. Res., 110, G02008, doi:10.1029/2005JG000042, 2005.

Baker, P. J. and Bunyavejchewin, S.: Fire behavior and fire effects across the forest landscape mosaics of continental Southeast Asia, in: Tropical Fire Ecology: Climate Change, Land Use and Ecosystem Dynamics, edited by: Cochrane, M. A., SpringerPraxis, Heidelberg, Germany, 311-334, 2009.

Benscoter, B., Thompson, D., Waddington, J. M., Wotton, M., Flannigan, M., de Groot, W., and Turetsky, M. R.: Interactive effects of vegetation, soil moisture, and bulk density on depth of burning of thick organic soils, Int. J. Wildland Fire, 20, 418-429, 2011.

Bonan, G. B., Levis, S., Kergoat, L., and Oleson, K. W.: Landscapes as patches of plant functional types: An integrating concept for climate and ecosystem models, Global Biogeochem. Cy., 16, 1021, doi:10.1029/2000GB001360, 2002.

Bond, W. J., Woodward, F., and Midgley, G. F.: The global distribution of ecosystems in a world without fire, New Phytol., 165, 525-538, doi:10.1111/j.1469-8137.2004.01252.x, 2004.

Bond-Lamberty, B., Peckham, S. D., Gower, S. T., and Ewers, B. E.: Effects of fire on regional evapotranspiration in the central Canadian boreal forest, Glob. Change Biol., 15, 1242-1254. doi:10.1111/j.1365-2486.2008.01776.x, 2009.

Bowman, D. M. J. S., Balch, J. K., Artaxo, P., Bond, W. J., Carlson, J. M., Cochrane, M. A., D’Antonio, C. M., DeFries, R. S., Doyle, J. C., Harrison, S. P., Johnston, F. H., Keeley, J. E., Krawchuk, M. A., Kull, C. A., Marston, J. B., Mortiz, M. A., Prentice, I. C., Roos, C. I., Scott, A. C., Swetnam, T. W., van der Werf, G. R., and Pyne, S. J.: Fire in the Earth System, Science, 324, 480-484, doi:10.1126/science.1163886, 2009.

Bowman, D. M. J. S., Balch, J. K., Artaxo, P., Bond, W. J., Cochrane, M. A., D’Antonio, C. M., DeFries, R., Johnston, F. H., Keeley, J. E., Krawchuk, M. A., Kull, C. A., Mack, M., Moritz, M. A., Pyne, S., Roos, C. I., Scott, A. C., Sodhi, N. S., and Swetnam, T. W.: The human dimension of fire regimes on Earth, J. Biogeogr., 38, 2223-2236, doi: 10.1111/j.13652699.2011.02595.x, 2011.

Carvalho, J. A., Costa, F. S., Veras, C. A. G., Sandberg, D. V., Alvarado, E. C., Gielow, R., Serra, A. M., and Santos, J. C.: Biomass fire consumption and carbon release rates of rainforestclearing experiments conducted in northern Mato Grosso, Brazil, J. Geophys. Res., 106, 17877-17887, 2001.
Chen, T.-X. and Chen W.-B.: The relationship between forest fire and meteorological elements and the forest of forest fire grades and forest fire's defence, Meterology Journal of Henan, 20002004, 25-26, 2000.

Chen, Y., Randerson, J. T., Morton, D. C., DeFries, R. S., Collatz G. J., Kasibhatla, P. S., Giglio, L., Jin, Y., and Marlier, M. E.: Forecasting fire season severity in South America using sea surface temperature anomalies, Science, 334, 787-791, 2011.

Chidumayo, E. N.: A shifting cultivation land use system under population pressure in Zambia, Agroforest. Syst., 5, 15- 25, 1987.

Chuvieco, E., Giglio, L., and Justice, C.: Global characterization of fire activity: Toward defining fire regimes from Earth observation data, Glob. Change Biol., 14, 1488-1502, doi:10.1111/j.13652486.2008.01585.x, 2008.

CIESIN: Gridded population of the world version 3(GPWv3): Population density grids, Technical report, Socioeconomic Data and Applications Center (SEDAC), Columbia University, Palisades, New York, USA, 2005.

Cochrane, M. A.: Fire science for rainforests, Nature, 421, 913-919, 2003.

Cochrane, M. A. and Ryan, K. C.: Fire and fire ecology: Concepts and principles, in: Tropical Fire Ecology: Climate Change, Land Use and Ecosystem Dynamics, edited by: Cochrane, M. A., Springer-PRAXIS, Heidelberg, Germany and Chichester, UK, 25-62, 2009.

Ferretti, D. F., Miller, J. B., White, J. W. C., Etheridge, D.M., Lassey, K. R., Lowe, D. C., MacFarling Meure, C. M., Dreier, M. F., Trudinger, C. M., van Ommen, T. D., and Langenfelds, R. L.: Unexpected changes to the global methane budget over the past 2000 years, Science, 309, 1714-1717, 2005.

Field, R. D., van der Werf, G. R., and Shen, S. S. P.: Human amplification of drought-induced biomass burning in Indonesia since 1960, Nat. Geosci., 2, 185-188, doi:10.1038/NGEO443, 2009.

GACGC: World in transition: Strategies for managing global environmental risks, German Advisory Council on Global Change, Annual Report 1998, Berlin, 2000.

Giglio, L., Csiszar, I., and Justice, C. O.: Global distribution and seasonality of active fires as observed with the Terra and Aqua Moderate Resolution Imaging Spectroradiometer (MODIS) sensors, J. Geophys. Res., 111, G02016, doi:10.1029/2005JG000142, 2006.

Giglio, L., Randerson, J. T., van der Werf, G. R., Kasibhatla, P. S., Collatz, G. J., Morton, D. C., and DeFries, R. S.: Assessing variability and long-term trends in burned area by merging multiple satellite fire products, Biogeosciences, 7, 1171-1186, doi:10.5194/bg-7-1171-2010, 2010.

Gill, A. M., Williams, R. J., and Woinarski, C. Z.: Fires in Australia's tropical savannas: Interactions with biodiversity, global warming, and exotic biota, in: Tropical Fire Ecology: Climate Change, Land Use and Ecosystem Dynamics, edited by: Cochrane, M. A., Springer-Praxis, Heidelberg, Germany, 263283, 2009.

Hansen, M. C., DeFries, R. S., Townshend, J. R. G., Carroll, M., Dimiceli, C., and Sohlberg, R. A.: Global percent tree cover at a spatial resolution of 500 meters: first results of the MODIS vegetation continuous fields algorithm, Earth Interact., 7, 1-15, 2003. 
Hansen, M. C., Stehman, S. V., Potapov, P. V., Loveland, T. R., Townshend, J. R. G., DeFries, R. S., Pittman, K. W., Arunarwati, B., Stolle, F., Steininger, M. K., Carroll, M., and DiMiceli, C.: Humid tropical forest clearing from 2000 to 2005 quantified by using multitemporal and multiresolution remotely sensed data, P. Natl. Acad. Sci. USA, 105, 9439-9444, doi:10.1073/pnas.0804042105, 2008.

Hoffmann, A. A., Parry, J.-E., Cuambe, C., Kwesha, D., and Zhakata, W.: Climate change and wildland fires in Mozambique, in: Tropical Fire Ecology: Climate Change, Land Use and Ecosystem Dynamics, edited by: Cochrane, M. A., SpringerPraxis, Heidelberg, Germany, 263-283, 2009.

Holdsworth, A. R. and Uhl, C.: Fire in Amazonian selectively logged rain forest and the potential for fire reduction, Ecol. Appl., 7, 713-725, 1997.

Houghton, R. A., Hobbie, J. E., Melillo, J. M., Moore, B., Peterson, B. J., Shaver, G. R., and Woodwell, G. M.: Changes in the carbon content of terrestrial biota and soils between 1860 and 1980: a net release of $\mathrm{CO}_{2}$ to the atmosphere, Ecol. Monogr., 53, 235-262, 1983.

Houweling, S., van der Werf, G., Goldewijk, K. K., Röckmann, T., and Aben, L.: Early anthropogenic emissions and the variation of $\mathrm{CH}_{4}$ and ${ }^{13} \mathrm{CH}_{4}$ over the last millennium, Global Biogeochem. Cy., 22, GB1002 10.1029/2007GB002961, 2008.

Hurtt, G. C., Frolking, S., Fearon, M. G., Moore, B., Shevliakova, E., Malyshev, S., Pacala, S. W., and Houghton, R. A.: The underpinnings of land-use history: three centuries of global gridded land-use transitions, wood-harvest activity, and resulting secondary lands, Glob. Change Biol., 12, 1208-1229, doi:10.1111/j.1365-2486.2006.01150.x, 2006.

IPCC: Climate Change 2007: The Physical Science Basis, Contribution of Working Group I to the Fourth Assessment Report of the Intergovernmental Panel on Climate Change, edited by: Solomon, S., Qin, D., Manning, M., Chen, Z., Marquis, M., Averyt, K. B., Tignor, M., and Miller, H. L., Cambridge University Press, Cambridge, UK and New York, NY, USA, 2007.

Justice, C. O., Townshend, J. R. G., Vermote, E. F., Masuoka, E., Wolfe, R. E., Saleous, N., Roy, D. P., and Morisette, J. T.: An overview of MODIS Land data processing and product status, Remote Sens. Environ., 83, 3-15, 2002.

Kalnay, E., Kanamitsu, M., Kistler, R., Collins, W., Deaven, D., Gandin, L., Iredell, M., Saha, S., White, G., Woollen, J., Zhu, Y., Leetmaa, A., Reynolds, R., Chelliah, M., Ebisuzaki, W., Higgins, W., Janowiak, J., Mo, K. C., Ropelewski, C., Wang, J., Jenne, R., and Joseph, D.: The NCEP/NCAR 40-Year Reanalysis Project, B. Am. Meteorol. Soc., 77, 437-471, 1996.

Klein Goldewijk, K., Beusen, A., and Janssen, P.: Long term dynamic modeling of global population and built-up area in a spatially explicit way, HYDE 3.1, The Holocene, 20, 565-573, 2010.

Kloster, S., Mahowald, N. M., Randerson, J. T., Thornton, P. E., Hoffman, F. M., Levis, S., Lawrence, P. J., Feddema, J. J., Oleson, K. W., and Lawrence, D. M.: Fire dynamics during the 20th century simulated by the Community Land Model, Biogeosciences, 7, 1877-1902, doi:10.5194/bg-7-1877-2010, 2010.

Korontzi, S., McCarty, J., Loboda, T., Kumar, S., and Justice, C.: Global distribution of agricultural fire in croplands from 3 years of Moderate Resolution Imaging Spectroradiometer (MODIS) data, Global Biogeochem. Cy., 20, GB2021, doi:10.1029/2005GB002529, 52006.
Lawrence, D., Oleson, K. W., Flanner, M. G., Thorton, P. E., Swenson, S. C., Lawrence, P. J., Zeng, X., Yang, Z. L., Levis, S., Skaguchi, K., Bonan, G. B., and Slater, A. G.: Parameterization Improvements and Functional and Structural Advances in Version 4 of the Community Land Model, J. Adv. Model. Earth Syst., 3, M03001, doi:10.1029/2011MS000045, 2011.

Lawrence, P. J. and Chase, T. N: Representing a new MODIS consistent land surface in the Community Land Model (CLM 3.0), J. Geophys. Res., 112, G01023, doi:10.1029/2006JG00016, 2007.

Lawrence, P. J. and Chase, T. N.: Investigating the climate impacts of global land cover change in the community climate system model, Int. J. Climatol., 30, 2066-2087, 2010.

Lehner, B. and Döll, P.: Development and validation of a global database of lakes, reservoirs and wetlands, J. Hydrol., 296, 1-22, 2004.

Lehsten, V., Tansey, K., Balzter, H., Thonicke, K., Spessa, A., Weber, U., Smith, B., and Arneth, A.: Estimating carbon emissions from African wildfires, Biogeosciences, 6, 349-360, doi:10.5194/bg-6-349-2009, 2009.

Lenihan, J. M. and R. P. Neilson: Simulating broad-scale fire severity in a dynamic global vegetation model, Northwest Sci., 72, 91-103, 1998.

Le Page, Y., Oom, D., Silva, J. M. N., Jönsson, P., and Pereira, J. M. C.: Seasonality of vegetation fires as modified by human action: observing the deviation from eco-climatic fire regimes, Global Ecol. Biogeogr., 19, 575-588, 2010a.

Le Page, Y., van der Werf, G. R., Morton, D. C., and Pereira, J. M. C.: Modeling fire-driven deforestation potential in Amazonia under current and projected climate conditions, J. Geophys. Res.Biogeo., 115, G03012, doi:10.1029/2009JG001190, 2010b.

Levis, S., Bonan, G. B., Vertenstein, M., and Oleson, K. W.: The Community Land Model's dynamic global vegetation model (CLM-DGVM): Technical description and user's guide, NCAR Tech. Note TN-459_IA, Terrestrial Sciences Section, Boulder, Colorado, 2004.

Li, F., Zeng, X. D., and Levis, S.: A process-based fire parameterization of intermediate complexity in a Dynamic Global Vegetation Model, Biogeosciences, 9, 2761-2780, doi:10.5194/bg-9-27612012, 2012a.

Li, F., Zeng, X. D., and Levis, S.: Corrigendum to "A process-based fire parameterization of intermediate complexity in a Dynamic Global Vegetation Model" published in Biogeosciences, 9, 27612780, 2012, Biogeosciences, 9, 4771-4772, doi:10.5194/bg-94771-2012, 2012b.

Logan, J. A.: Tropospheric ozone: seasonal behavior, trends and anthropogenic influence, J. Geophys. Res., 90, 10463-10482, 1985.

Logan, J. A., Prather, M. J., Wofsy, S. C., and McElroy, M. B.: Tropospheric Chemistry: A global perspective, J. Geophys. Res., 86, 7210-7254, 1981.

Luiz, E. O., Aragão, C., and Shimabukuo, Y. E., The incidence of fire in Amazonian forests with implications for REDD, 328, 1275-1278, 2010.

Magi, B. I., Rabin, S., Shevliakova, E., and Pacala, S.: Separating agricultural and non-agricultural fire seasonality at regional scales, Biogeosciences, 9, 3003-3012, doi:10.5194/bg-9-30032012, 2012.

Marlon, J. R., Bartlein, P. J., Carcaillet, C., Gavin, D. G., Higuera, P. E., Joos, F., Power, M. J., and Prentice, I. C.: Climate and human influences on global biomass burning over the past two millennia, 
Nat. Geosci., 1, doi:10.1038/ngeo313, 2008.

Mollicone, D, Eva, H. D, and Achard, F: Human impact on 'wild' fires in boreal Eurasian forests, Nature, 440, 436-437, 2006.

Morton, D. C., DeFries, R. S., Randerson, J. T., Giglio, L., Schroeder, W., and van der Werf, G. R.: Agricultural intensification increases deforestation fire activity in Amazonia, Glob. Change Biol., 14, 2262-2275, doi:10.1111/j.13652486.2008.01652.x, 2008

New, M., Hulme, M., and Jones, P.: Representing twentieth century space-time climate variability. Part I: Development of a 1961-90 mean monthly terrestrial climatology, J. Climate, 12, 829-856, 1999.

New, M., Hulme, M., and Jones, P.: Representing twentieth-century space-time climate variability. Part II: Development of 1901-96 monthly grids of terrestrial surface climate, J. Climate, 1, 22172238, 2000.

Oleson, K. W., Lawrence, D. M., Bonan, G. B., Flanner, M. G., Kluzek, E., Lawrence, P. J., Levis, S., Swenson, S. C., Thornton, P. E., Dai, A., Decker, M., Dickinson, R., Feddema, J., Heald, C. L., Hoffman, F., Lamarque, J. F., Mahowald, N. M., Niu, G. Y., Qian, T., Randerson, J., Running, S., Sakaguchi, K., Slater, A., Stockli, R., Wang, A., Yang, Z.-L., Zeng, X.-D., and Zeng, X.: Technical description of version 4.0 of the Community Land Model, NCAR Tech. Note NCAR/TN-478+STR, Terrestrial Sciences Section, Boulder, Colorado, 2010.

Olson, D. M., Dinerstein, E.,Wikramanayake, E. D., Burgess, N. D., Powell, G. V. N., Underwood, E. C., D’Amico, J. A., Itoua, I., Strand, H. E., Morrison, J. C., Loucks, C. J., Allnutt, T. F., Ricketts, T. H., Kura, Y., Lamoreux, J. F., Wettengel, W. W., Heda, P., and Kassem, K. R.: Terrestrial ecoregions of the world a new map of life on earth, Bioscience, 51, 933-938, 2001.

Page, S. E., Siegert, F., Rieley, J. O., Boehm, H.-D. V., Jaya, A., and Limin, S.: The amount of carbon released from peat and forest fires in Indonesia in 1997, Nature, 420, 61-65, 2002.

Page, S. E., Hoscilo, A., Langner, A., Tansey, K. J., Siegert, F., Limin, S., and Rieley, J. O.: Tropical peatland fires in Southeast Asia, in: Tropical Fire Ecology: Climate Change, Land Use and Ecosystem Dynamics, edited by: Cochrane, M. A., SpringerPraxis, Heidelberg, Germany, 263-283, 2009.

Pechony, O. and Shindell, D. T.: Fire parameterization on a global scale, J. Geophys. Res., 114, D16115, doi:10.1029/2009JD011927, 2009.

Pechony, O. and Shindell, D. T.: Driving forces of global wildfires over the past millennium and the forthcoming century, P. Natl. Acad. Sci. USA, 107, 19167-19170, doi:10.1073/pnas.1003669107, 2010.

Prentice, I. C.: The burning issue, Sciences, 330, 1636-1637, 2010.

Prentice, I. C., Kelley, D. I., Foster, P. N., Friedlingstein, P., Harrison, S. P., and Bartlein, P. J.: Modeling fire and the terrestrial carbon balance, Global Biogeochem. Cy., 25, GB3005, doi:10.1029/2010GB003906, 2011.

Qian, T., Dai, A., Trenberth, K. E., and Oleson, K. W.: Simulation of global land surface conditions from 1948 to 2004. Part I: Forcing data and evaluations, J. Hydrometeorol., 7, 953-975, 2006.

Ramankutty, N., Evan, A. T., Monfreda, C., and Foley, J. A.: Farming the planet: 1. Geographic distribution of global agricultural lands in the year 2000, Global Biogeochem. Cy., 22, GB1003, doi:10.1029/2007GB002952, 2008.
Randerson, J. T., Chen, Y., van der Werf, G. R., Rogers, B. M., and Morton D.: Small fire contributions to global burned area and biomass burning emissions, J. Geophys. Res., 117, G04012, doi:10.1029/2012JG002128, 2012.

Ray, D., Nepstad, D., and Moutinho, P.: Micrometeorological and canopy controls of fire susceptibility in a forested Amazon landscape, Ecol. Appl., 15, 1664-1678, 2005.

Saarnak, C. F.: A shift from natural to human-driven fire regime: implications for trace-gas emissions, Holocene, 11, 373-375, 2001.

Saatchi, S., Marlier, M., Chazdon, R. L., Clark, D. B., and Russell, A. E.: Impact of spatial variability of tropical forest structure on radar estimation of aboveground biomass, Remote Sens. Environ., 115, 2836-2849, 2011.

Schroeder, W., Morisette, J. T., Csiszar, I., Giglio, L., Morton, D., and Justice, C. O.: Characterizing vegetation fire dynamics in Brazil through multisatellite data: Common trends and practical issues, Earth Interact., 9, 1-26, 2005.

Tarnocai, C., Kettles, I. M., and Lacelle, B.: Peatlands of Canada, Geological Survey of Canada, Open File 6561, CD-ROM, 2011.

Thonicke, K., Venevsky, S., Sitch, S., and Cramer, W.: The role of fire disturbance for global vegetation dynamics: Coupling fire into a Dynamic Global Vegetation Model, Global Ecol. Biogeogr., 10, 661-677, 2001.

Thonicke, K., Spessa, A., Prentice, I. C., Harrison, S. P., Dong, L., and Carmona-Moreno, C.: The influence of vegetation, fire spread and fire behaviour on biomass burning and trace gas emissions: results from a process-based model, Biogeosciences, 7, 1991-2011, doi:10.5194/bg-7-1991-2010, 2010.

Thornton, P. E., Lamarque, J., Rosenbloom, N., and Mahowald, N. M.: Influence of carbon-nitrogen cycle coupling on land model response to $\mathrm{CO}_{2}$ fertilization and climate variability, Global Biogeochem. Cy., 21, GB4018, doi:10.1029/2006GB002868, 2007.

Turetsky, M. R., Wieder, R. K., Halsey, L. A., and Vitt, D. H.: Current disturbance and the diminishing peatland carbon sink, Geophys. Res. Lett., 29, 1526, doi:10.1029/2001GL014000, 2001.

Turetsky, M. R., Amiro, B. D., Bosch, E., and Bhatti, J. S.: Historical burn area in western Canadian peatlands and its relationship to fire weather indices, Global Biogeochem. Cy., 18, GB4014, doi:10.1029/2004GB002222, 2004.

Uhl, C. and Kauffman, J. B.: Deforestation, fire susceptibility, and potential responses to fire in the eastern Amazon, Ecology, 71, 437-449, 1990.

UNSTAT: National Accounts Main Aggregates Database, United Nations Statistics Division, 2005.

van der Werf, G. R., Randerson, J. T., Giglio, L., Gobron, N., and Dolman, A. J.: Climate controls on the variability of fires in the tropics and subtropics, Global Biogeochem. Cy., 22, GB3028, doi:10.1029/2007GB003122, 2008.

van der Werf, G. R., Morton, D. C., DeFries, R. S., Giglio, L., Randerson, J. T., Collatz, G. J., and Kasibhatla, P. S.: Estimates of fire emissions from an active deforestation region in the southern Amazon based on satellite data and biogeochemical modelling, Biogeosciences, 6, 235-249, doi:10.5194/bg-6-235-2009, 2009.

van der Werf, G. R., Randerson, J. T., Giglio, L., Collatz, G. J., Mu, M., Kasibhatla, P. S., Morton, D. C., DeFries, R. S., Jin, Y., and van Leeuwen, T. T.: Global fire emissions and the contribution of deforestation, savanna, forest, agricultural, and peat fires (19972009), Atmos. Chem. Phys., 10, 11707-11735, doi:10.5194/acp10-11707-2010, 2010. 
Van Vuuren, D. P., Lucas, P. S., and Hilderink, H. B. M., Downscaling drivers of global environmental change: Enabling use of global SRES scenarios at the national and grid levels, Netherlands Environmental Assessment Agency, Report 550025001, 45 pp., 2006.

Vertenstein, M., Craig, T., Middleton, A., Feddema, D., and Fischer, C.: CESM1.0.4 User's Guide, available at: http://www.cesm. ucar.edu/models/cesm1.0/cesm/cesm_doc_1_0_4/ug.pdf, 2012.

Wang, Z., Chappellaz, J., Park, K., and Mark, J. E.: Large variations in Southern Hemisphere biomass burning during the last 650 years, Science, 330, 1663-1666, 2010.

Williams, R. J., Gill, A. M., and Moore, P. H. R.: Seasonal changes in fire behaviour in a tropical Savanna in Northern Australia, Int. J. Wildland Fire, 8, 227-239, 1998.
World Bank: World development indicators 2004, Oxford University Press, New York, 416 pp., 2004.

World Health Organization (WHO): Vegetation fires, Geneva, Switzerland, Fact Sheet 254, 2000.

Zeng, X.-D.: Evaluating the dependence of vegetation on climate in an improved dynamic global vegetation model, Adv. Atmos. Sci., 27, 977-991, doi:10.1007/s00376-009-9186-0, 2010.

Zeng, X.-D., Zeng, X., and Barlage, M.: Growing temperate shrubs over arid and semiarid regions in the NCAR Dynamic Global Vegetation Model (CLM-DGVM), Global Biogeochem. Cy., 22, GB3003, doi:10.1029/2007GB003014, 2008.

Zhou, G.-S. and Lu, Q.: Meteorology and Fires in Forests and Grassland, China Meteorological Press, Beijing, 2009. 